\title{
AZ IDŐ ASPEKTUSAI \\ GONDOLATOK AZ ÜZLETI STRATÉGIA ÉS TERVEZÉS FEJLESZTÉSÉHEZ
}

A szerzố dolgozatában az idő szerepét vizsgálja a versenyképes vállalati múködés aspektusában. Az idő szerepének érzékeltetésére - rövid ,elméleti alapvetést” követốen - először azt kísérli meg áttekinteni, hogy mi jellemzi az idố ütemének változását. Majd azt vázolja fel, hogy milyen idôtípusok játszanak szerepet a vállalatok üzleti stratégiájának és terveinek kialakításában. Ezt követốen sorra veszi a vállalatok vezetésében megjelenố idófogalmakat. Végül részletesen bemutatja a 3MAST modellt.

\section{Kulcsszavak: idôtípusok, vállalati stratégia, versenyképesség, menedzsment}

A közgazdász - több nyugat-európai előadótársával együtt - türelmetlenül toporog a 80-as évek derekán egy dnyepropetrovszki szálloda halljában. Már háromnegyed órája elmúlt ugyanis, hogy bele kellett volna kezdeniük mondókájukba egy „teach-in” szemináriumon a negyedórás buszútra fekvô színházteremben. A vendéglátók azonban nem indítják a társaságot, habár a busz ott áll a szálloda elôtt. Ezt végül ingerülten teszi szóvá a társaság egyik tagja. S erre a szervezók így válaszolnak: „Nem kell sietni. Ha nem késünk legalább másfél órát, a hallgatóság azt fogja hinni, hogy önök nem is fontos emberek." - Ezt itt és ekkor megérti a közgazdász.

A közgazdászt nagy megtiszteltetés éri. Amíg egy coloradói egyetemen sertepertél, az ottani kereskedelmi kamara vezetôi felkérik, hogy tartson előadást a helybéli üzletemberek negyedéves ebédjén az akkor friss kelet-európai politikai és gazdasági rendszerváltásokról, s azokról az esélyekról, amelyeket a rendszerváltások nyitnak meg a nyugati vállalkozók elótt. A közgazdász megkérdezi, mennyi idő áll ehhez a rendelkezésére? Közlik vele, hogy harmincöt perc. A közgazdász alkudozni kezd, hiszen hatalmas a téma: legyen legalább negyvenöt! A válasz: „Hosszabb ideig is beszélhetsz, de akkor légy felkészülve, hogy a társaság fele elmegy harmincöt perc után - mert ezek üzletemberek, akiknek percre be van osztva az idejük." - A közgazdász ott és akkor ezt is megérti.

A közgazdász ismeretterjesztó tudományos elóadást hallgat Budapesten. „Képzeljünk el egy ikerpárt”
- mondja az előadó. „Egyikük hosszú űrutazást tesz egy közel fénysebességgel száguldó úrhajóban. Visszatérése után sokkal fiatalabb lesz, mint a Földön maradó ikertestvére. Ezt nevezik ikerparadoxonnak ámbár csak akkor beszélhetnénk itt paradoxonról, ha tudatunk mélyén az abszolút idő elvét dédelgetnénk. A relativitáselméletben ugyanis nem létezik abszolút idő; ehelyett mindannyiunknak saját belsố idômércénk van, mely attól függ, hol tartózkodunk és hogyan mozgunk. ${ }^{1}$ Vagyis az abszolút időt (melyben minden óra egyformán ketyeg, s ezért mindnyájan ugyanazt az idốt érzékeljük) felváltotta a mindenkori észlelő tartózkodási helyétől és a mozgásától függố relatív idô." - S ezt már (noha természettudósok elótt szégyellné bevallani) nem érti meg a közgazdász.

\section{A téma behatárolása}

Ideje lenne tehát, hogy - már csak említett élményei miatt is - a közgazdász végre tisztába tegye önmagában az idő fogalmát. Annál is inkább, mert régóta hirdeti: a menedzsereknek négy tényezócssoportot kell elemezniük és értékelniük a hatékony üzleti stratégia megtervezésekor ahhoz, hogy vállalatuk hosszú távon sikeres legyen. Ezek a témacsoportok a következők:

(a) A vállalat tevékenységi körébe tartozó múszaki fejlődés trendjének összehasonlító elemzése, méghozzá a globális környezet egészében, a trendet reprezentáló szereplóket vizsgálva. ${ }^{2}$ Az elemzés célja 
annak feltárása, hogy hol, mikor, milyen mértékben és milyen tényezők hatására következett be a fejlődés az élvonalat képviselô, valamint az azt szorosabban és távolabbról követô vállalatok körében. Ennek az összehasonlító elemzésnek a technikája a WARD2,, a World-wide Analysis of Reasons of Dissimilar Development ${ }^{3}$. (1. ábra)

\section{A versenyképesség négydimenziós modellje}

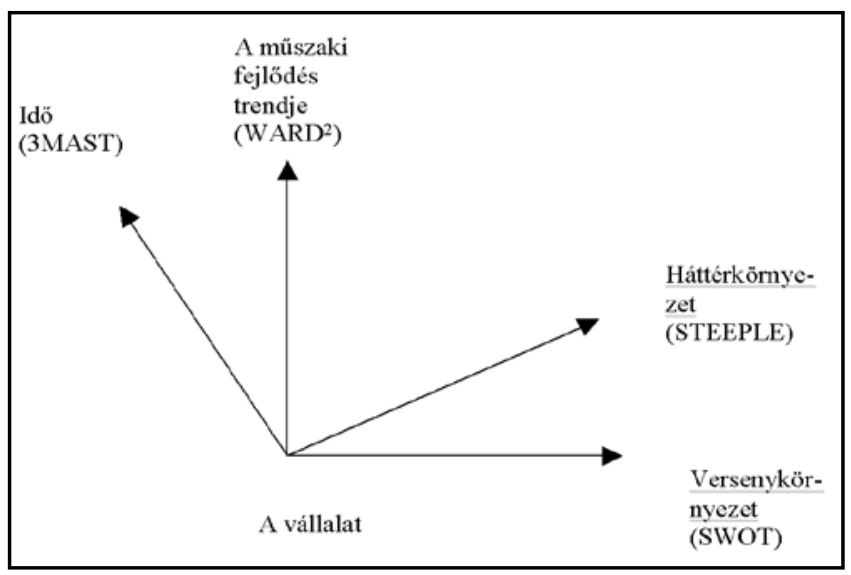

(b) A vállalat versenykörnyezetének vizsgálata. Ennek módszere a környezet által kínált új lehetôségeknek és az onnan érkezó új fenyegetéseknek, valamint ezek fényében - a vállalat erôs oldalainak és gyenge pontjainak azonosítása a jól ismert SWOT ${ }^{4}$ technikával. Újdonság viszont, hogy gyorsan változó világunkban már három „metszetben” célszerú elvégezni a SWOT-elemzést: a jelenben, a még kelló biztonságban prognosztizálható jövő́ben, valamint annak számbavételével, hogy az elemzés alapján kialakított stratégiára várhatóan milyen ellenlépésekkel válaszolnak majd a versenytársak. Erre utal az indexes $\mathrm{SWOT}_{(\mathrm{p}, \mathrm{f}, \mathrm{r})}$ betûszó.

(c) A harmadik tényezőcsoport a versenykörnyezet háttérkörnyezetének elemzése. A korábbi PEST-elemzés újabban STEEPLE-re bővült, amelyik - mint ma már közismert - a társadalmi, technikai, gazdasági, környezetgazdálkodási, politikai, jogi és oktatási háttérkörnyezet-elemeket ${ }^{5}$ jelzi. A környezet globálissá bővülése pedig azt indokolja, hogy ezt a vizsgálatot is három metszetben tanácsos elvégezni: a vállalat hazai környezetében, nemzetközi gazdasági kapcsolatainak körében és a világgazdaság egészében mint a legátfogóbb háttérkörnyezetben. Ezt jelzi indexével a STEEPLE $E_{(h, o, g)}$.

(d) Végül a negyedik tényezô az idő, amelyben végbemennek a változások mind az előzó három tényezőcsoportban, mind magában a vállalatban. Az idő ugyanis eltérő jellegú és egyre nagyobb kihívások- kal szembesíti a vállalatokat, illetve nagy és tartalmukban eltérő lehetőségeket nyit meg számukra. Az idô sajátosságainak elemzését segíti a 3MAST technika (a Three-mirror Model to Analyse the Speed of Time), amelyik hármas „tükörmodell” tényezói alapján vizsgálja az idő jellegzetességeiben rejlő lehetőségeket és fenyegetéseket.

Az idô szerepének érzékeltetésére - rövid „elméleti alapvetést" követôen - először azt kíséreljük meg áttekinteni, hogy mi jellemzi az idô ütemének változását. Majd azt vázoljuk, hogy milyen idótípusok játszanak szerepet a vállalatok üzleti stratégiájának és terveinek kialakításában. Ezt követôen sorra vesszük a vállalatok vezetésében megjelenô idófogalmakat. Végül részletesen bemutatjuk a 3MAST modellt.

\section{Elméleti alapvetés: idôütemek, négy „idôtípus” és néhány jellegzetes idôfogalom}

A vállalati stratégia és az operatív tervezés nézőpontjából mindenekelőtt azt kell számba venni, hogy milyen alapvetố idóütemekkel szembesülnek a vállalatok vezetôi.

- Elméletileg három jellegzetes idóütem létezik: $a$ gyorsulás, a lassulás és a változatlan ütem. Rögtön felvetôdik azonban a kérdés, hogy mihez képest gyorsul vagy lassul az idó, illetve marad változatlan az üteme? Az üzleti stratégia és operatív tervezés szempontjából három vonatkozásban vizsgálható egy vállalat ${ }^{6}$,,idôüteme”: összemérhető versenykörnyezetével (leginkább legnagyobb konkurensének stratégiai és operatív időütemével), háttérkörnyezetének ütemével (ezen belül is megkülönböztethetô a nemzetgazdaságára, a régiójára és a globális háttér egészére jellemző ütem), valamint a vállalat saját időüteméhez viszonyított gyorsulás, lassulás vagy változatlan ütem. Nyilvánvaló, hogy piacgazdaságban a versenykörnyezet üteméhez mért gyorsulásnak és lassulásnak van kiemelt szerepe.

- Az idő gyorsulását vagy lassulását döntően két tényező befolyásolja: az adott időszakaszban bekövetkező események száma, valamint ezek jelentôsége (súlya). Általános tapasztalat, hogy sok esemény közepette „röpül az idő”, események híján viszont csak nagy nehezen múlik. Vagyis az események száma és az idôütem változása egyenesen arányos. Ezt azonban rögtön pontosítani kell: ebben az összefüggésben az üzleti stratégia és az operatív tervezés szempontjából csak a releváns események számítanak - és globalizálódó világunkban, amelyben már nem csupán hatásokkal, hanem egyre hosszabb hatáslán- 
cokkal, egyre szétágazóbb hatáshálókkal, sốt egész gazdaságokat átható hatásmezókkel számolhatunk, az igazán fogas kérdés éppen a relevancia eldöntése. $\mathrm{Az}$ események jelentôsége pedig kétféleképpen is befolyásolhatja egy szervezetben az idô alakulását: felgyorsíthatja, ha a szervezet és vezetése rugalmas, ha jó a reagálóképessége - és lelassíthatja, akár le is béníthatja, ha felkészületlen és nem képes a gyors reagálásra. Ezért egy esemény jelentôsége (súlya) és a vállalat időüteme között lehet egyenes és fordított is az arány.

- Az idôütem hat szinten érzékelhetố: globális, regionális (például európai uniós), országos, társadalmi (elsősorban kulturális), nemzetgazdasági, vállalati és egyéni szinten. Az üzleti stratégia és operatív tervezés számára mind a hat szint meghatározó lehet. Mégis ezek közül korlátozni kell a globális szint tartalmát, nehogy ennek számbavétele ,parttalan feladattá" váljék a vállalat számára. Ezért az javasolható, hogy egy vállalat vezetése - talán a multinacionális óriásvállalatok vezetésének kivételével - három országcsoportban kísérje figyelemmel az időütem változását: 1 . Elemezze annak változását a „mozdonyországokban”, amelyek döntóen hatnak a világgazdaság fejődésére (ilyen napjainkban az USA, a távolabbi jövőben talán ilyen lesz Kína). 2. Árgus szemekkel figyelje az ütem változását az , $a k$ namezós országokban", amelyek akkor hatnak igazán a világgazdasági folyamatokra, ha súlyos gazdasági nehézségekkel szembesülnek (ezek fenyegették a közelmúltban Argentínát, Brazíliát, Indonéziát és Mexikót). 3. Folyamatosan érzékelje az időütem változását a „partnerországokban”, vagyis azokban, amelyek piaci szereplőivel vállalata jelentôs üzleti kapcsolatokat épített ki.

- Az idố gyorsulása, illetve lassulása külön fogalmi kategória, amelyik nem vehetô egy kalap alá a gazdasági fejlódéssel, illetve visszaeséssel. Igaz, a gazdasági fejlődés általában felgyorsítja az idôt - legyen ennek az alapja a múszaki fejlődés egy átütő erejú újdonsága, a nemzeti össztermék kiugró mértékú növekedése, a végsố fogyasztók keresletének váratlan felfutása egy helyi piacon, avagy bármilyen más ok. Viszont az is lehetséges, hogy számottevő mértékben gyorsul egy nemzetgazdaságban az idő - mégis, az ott honos és/vagy ott múködő vállalat múködésének üteme vészesen csökken. S egy gazdasági visszaesés esetében is ugyanez a helyzet, hiszen például a vállalat létét fenyegetô gazdasági recesszió felgyorsíthatja a vállalat időütemét: ennek az a feltétele, hogy menedzsmentje olyan válságmenedzselést kezdjen, amely jelentősen felgyorsít múködési folyamatokat a visszaesés fenye- getéseinek elkerülésére. Ugyanígy nem mechanikus az összefüggés egy vállalat fejlődése (növekedése, üzleti sikere) és a múködését jellemző idő gyorsulása, illetve lassulása között sem. Az üzleti siker és az időütemváltozás kapcsolatát általában egy 180 fokban elfordított csonka haranggörbe írja le a 2. ábra szerint. Az ábra azt érzékelteti, hogy az üzleti siker időszakában gyors a múködés ideje, a siker csökkenésének szakaszában pedig egyre nagyobb mértékben lelassul - akár a csökkenés okaként, akár annak következményeként; és ha a vállalat túljut sikertelenségének holtpontján - amelyik után már óhatatlanul a felszámolása következnék be -, ismét felgyorsul a múködési idő, hogy ezzel váljék lehetővé a kilábalás.

2. ábra

A vállalat üzleti sikerének és

múködési idôváltozásának - gyorsulásának és lassulásának - összefüggése

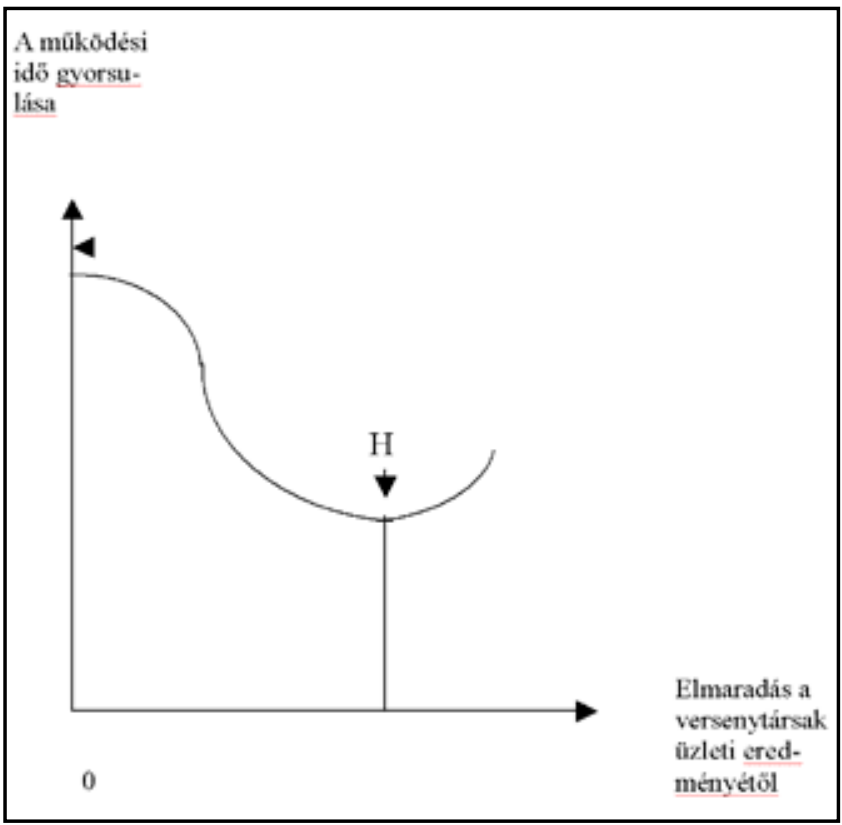

( $\mathrm{H}=$ holtpont

- A vállalatok vezetóinek azzal is számolniuk kell, hogy valós versenykörnyezetben (tehát nem az elmélet szempontjából nézve) sohasem múködhet egy sikeres vállalat ,változatlan ütemben”. És ez nem csupán az egyre gyorsuló fejlődés következménye. A mindennapok tapasztalata azt mutatja, hogy amelyik vállalat vezetése elfogadja még a konkurensekkel azonos ütemú múköóés tényét, az is lemarad. Korunk versenye ugyanis - akár egyetértünk ezzel, akár nem - az ütem folytonos növelését követeli meg nemcsak önmagához, tehát a vállalati „,belsô idő̈utemhez" képest, hanem környezetének idő̈uteméhez viszonyítva is. Vagyis egy harmadik időütem 
nem létezhet a menedzsment számára: a „változatlan ütem" óhatatlanul lelassulás.

- És végül mindezzel kapcsolatban egy másik gyakorlati következmény. Általános tapasztalat, hogy egy vállalat versenyelőnyre tehet szert, ha konkurenseinél gyorsabban reagál környezetének kihívásaira. Ezen a tapasztalaton belül azonban két sajátosságot is érdemes a menedzsmentnek számba vennie: a reagálás időigényének csökkenésével exponenciálisan nô a vállalat versenyelônye - de exponenciálisan nô a kockázat is, hogy a vezetés helyesen ismerte-e fel magát a kihívást és annak következményeit. Ezt a kettôs összefüggést szemlélteti a 3. ábra úgy, hogy egyre szélesedő sávokban jelzi mind a kihívásokra adható válaszlehetôségek versenyelőny-tartalmát, mind az ezekkel járó kockázat nagyságát.

3. ábra

Egy vállalat reagálási idejének, versenyelónyének és a helyes reagálás kockázatának összefüggése

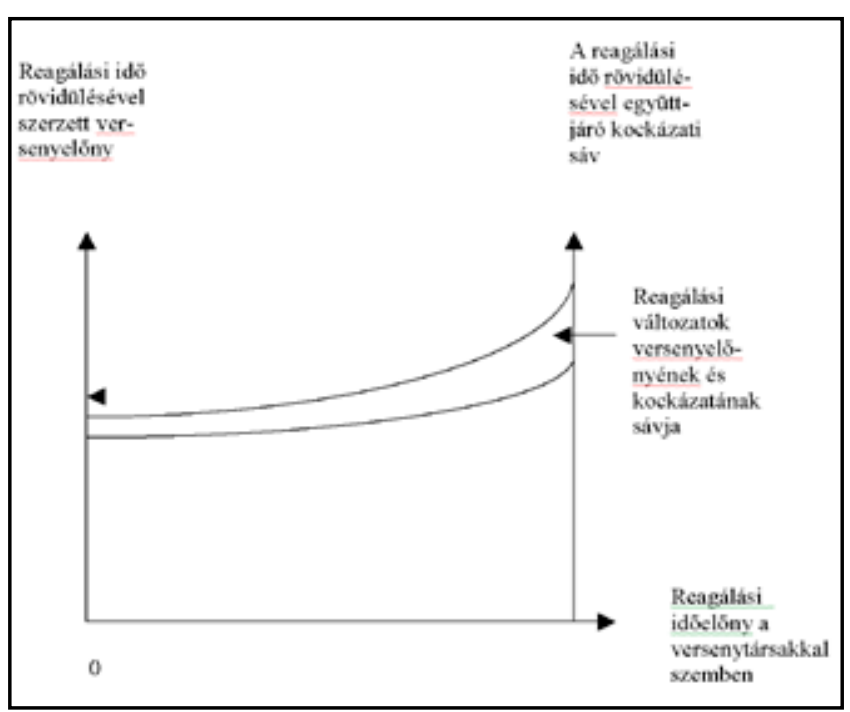

Ebból következik, hogy a menedzsmentnek - amikor reagál a környezet kihívására - soha nem szabad csak a minél gyorsabb, minél „rugalmasabb” reagálásra törekednie, hanem a válasz gyorsaságával együtt annak kockázatát is mérlegelnie kell. Vagyis a jó válasz két tényezó, a gyorsaság és a kockázat mértékének az optimuma.

Az időnek különböző tulajdonságai lehetnek, s ezek alapján másként és másként jelenhet meg. A legfontosabb tulajdonságokat és változataikat figyelembe véve jellegzetes időtípusok különböztethetốk meg. Az idótípusok pedig mintegy mozgásteret is jelölnek ki a vállalatvezetốk számára, hogy azon belül értelmezzék a külső és belsố környezet kihívásait és a lehetőségeit, valamint az ezekre adható vállalati válaszokat. Az üzleti stratégia és az operatív tervezés szempontjából két fontos tulajdonság két-két „szélsőértéke” szerint a következố négy idốtípus különböztethetô meg:

- Az objektív és törvényszerú időtípusban hajszálpontosan és az érzékelőtốl függetlenül múlik az idô környezetünkben például a newtoni világ természeti törvényei szerint, ahogy a Föld halad pályáján vagy forog tengelye körül, ahogy múlik az idô a fény terjedése alatt vagy a szabadesés feltételei között. Ilyen objektív és törvényszerú idô nem létezik a gazdasági életben. A makrogazdasági folyamatok elemzói sokszor törekednek ugyan olyan axiómák és tételek megfogalmazására, amelyek kielégítik az objektív és törvényszerú idôtípus követelményeit, ám ezt vagy megcáfolják az újabb és újabb események (például néhány évtizeddel ezelőtt a korábban elképzelhetetlen stagfláció jelensége), vagy a megfogalmazott „törvények” csupán akkor érvényesülnek, ha elfogadjuk a „,ceteris paribus” többé-kevésbé életidegen feltételezéseit. A mikrogazdaságban objektív és törvényszerú időt érzékelhetnének a vállalatok vezetői egyes makrogazdasági szabályozásokban (például adózásról szóló rendelkezésekben). Ám ezek a szabályozások inkább csak rövid távon minôsíthetốk objektív és törvényszerú idônek; hosszabb távon már az objektív és véletlenszerú időtípusba sorolhatók akár a kormányzatok változó gazdaságpolitikája és gazdaságszabályozó intézkedései, akár az egymásnak ellentmondó vagy tétovázó rendelkezéseik miatt. Vagyis sokszor még a mikrogazdaság szférájában is csupán egy „kvázi-objektív és törvényszerú” időtípus alakul ki. (Erre lesz példa a késóbbiekben a múszaki fejlesztés egyik problémája az „Idôtípusok, idôtípusváltások" címú fejezetben.)

- Az objektív és véletlenszerú időtípusban az érzékelő önmagától függetlennek tartja az idő múlását, s így éli meg annak váratlan változásait: hol gyorsulásával, hol pedig lassulásával szembesül. Napjainkban még a gazdaságilag leghatalmasabb országok kormányai, vagy a nagyhatalmú nemzetközi gazdasági szervezetek között sem akad olyan, amelynek vezetôi azt hihetnék, hogy maguk szabhatják meg az idő ütemét (például azzal, hogy globális és meghatározó mértékú befolyásuk lenne a gazdasági ciklusok alakulására). És még a multinacionális óriásvállalatok vezetói sem hihetik, hogy cégük olyan monopolhelyzethez közeli pozícióba juthat, amelyben maguk szabhatják meg a piac alakulását. A makro- és mikrogazdaság szereplői kénytelenek tehát elfogadni, hogy számos tốlük független és véletlenszerú jelenséggel szembesülnek - többek között annak az időnek a felgyorsulásával vagy lelassulásával, amely más és más feltételeket 
alakít ki régiók, nemzetgazdaságok és vállalatok számára egyaránt, s amelyben vezetôiknek a gyorsuláshoz vagy a lassuláshoz alkalmazkodva kell jó döntéseket hozniuk.?

- A szubjektív és törvényszerú időtípus feltételei között a menedzserek mesterségesen szabják meg önmagunk és/vagy irányított szervezetünk számára az idô múlását, s ehhez igazítják a kitûzött feladatok elvégzését. Pontosabban fogalmazva: időhatárokat szabnak meg, s a kitúzött feladatok teljesítéséhez az szükséges, hogy az idő a megfelelố ütemben teljék az időhatárok között. Vagyis a szubjektív és törvényszerú időtípus akkor sikeres, ha a tervezó (legyen akár makro-, akár mikrogazdasági célok és folyamatok tervezóje) megteremti az összhangot a tervezett idôhatárok mint követelmények és a határokon belül múló idố gyorsulása vagy lassulása között. (Jó példa erre az a vállalati vezetés, amelyik egy intervallumon belül „,kiemelt ösztönzéssel” gyorsítja fel az idoot, hogy így oldja fel a vállalati múködés idejében érzékelt „szúk keresztmetszetét”.) Kétségtelen, hogy nemritkán ilyen szinkron nélkül is eleget lehet tenni a követelményeknek, ám ez mindig ráfordítástöbblettel jár. A szubjektív és törvényszerú idôtípus létrehozásának végsố célja tehát makro- és mikroszinten egyaránt a szervezettség növelése, valamint a múködés javítása (ezen belül a munka- és minôségi fegyelem, a munkaintenzitás, a termelékenység, a hatékonyság stb. fokozása). Másként fogalmazva: a szubjektív és törvényszerú idôtípus lehetőségeinek kiaknázása még a turbulens változások korában is elengedhetetlen feltétele annak, hogy mind a nemzetgazdaságok, mind a vállalatok növelhessék - vagy legalábbis megőrizhessék - versenyképességüket.

- A szubjektív és véletlenszerú idótípust egy szervezet és az egyén egyaránt megéli. Egy szervezet számára - legyen akár makro-, akár mikrogazdasági szervezet - ez az időtípus teremti meg a lehetôséget, hogy válaszoljon az objektív és véletlenszerú időtípus kihívásaira. A szubjektív jelleg azonban a rossz válasz esélyét is magában hordja. Egy vállalat vezetése például eróforrás-átcsoportosítással lassíthatja a $\mathrm{K}+\mathrm{F}$ ütemét és felgyorsíthatja a termelését, mert úgy látja, hogy számottevő́n megnótt a cég piaci részesedése. Pedig valójában az történt, hogy nem az összkereslet nőtt meg, hanem csak a versenytársak vonultak ki hagyományos termékeikkel a piacról, mert már az új $\mathrm{K}+\mathrm{F}$ eredményeinek termékeit kezdték el kínálni. ${ }^{8}$ - Az egyének esetében pedig alkatuktól, életritmusuktól, kultúrájuktól, mindenkori közérzetüktől, érdekeltségüktôl stb. függ a szubjektív és véletlenszerú idő „megélése”. S minden vezető számára egyre fontosabb, hogy turbulens világunkban munkatársai ne „gépiesen” vegyenek részt a szervezet múködésében, hanem legyenek képesek például gyorsítani vagy lassítani, igazodva a szervezet váratlan és a környezete által kikényszerített időütemváltásaihoz. S ez azért is fontos követelmény, mert a szubjektív és véletlenszerú idő intenzív „megélése” az egyik legnagyobb versenyelőnyt, az egyén kreativitását és innovációs készségét, képességét is növeli.

A felsorolt négy idôtípuson belül kialakultak az idő folyamatában élók jellegzetes idófogalmai is. Témánk szempontjából tizenkét időfogalmat célszerú számításba venni:

1. Legáltalánosabb a kulturális idó fogalma: egy kultúrában többé-kevésbé azonosan értékeli az ott élốk többsége az idôt. Így létezhetnek - miként bevezetőnk első két példája utalt rá - „,perc-” és „óra-”, vagy akár „félnap-érzékeny” kultúrák.

2. A szervezeti idó egy adott szervezet vezetőinek és munkatársainak idóérzékenységére jellemző. Felgyorsult világunkban egy vállalat, intézmény, vagy akár egy kormányzat feszes időgazdálkodása, vagyis a rendelkezésre álló idő minél jobb kihasználása versenyképességük egyik fó feltétele lett. ${ }^{9}$

3. Az idó szinkronja vagy aszinkronja azt fejezi ki, hogy összhangban van-e egymással a vállalati belső és a környezeti külsố idô változása mind irányában (gyorsulásában vagy lassulásában), mind ütemében és tartósságában.

4. A reakcióidó általánosan ismert fogalom. Jelentôsége a közgazdaság, s azon belül a vállalatgazdaság területén újabban nőtt meg, fôként a környezetben bekövetkező események és eseményláncok történéseinek felgyorsulása miatt. A környezeti változások üteménél hosszabb reakcióidô - például a késedelmes reagálás a kereslet változására, vagy egy konkurens marketingakciójára - könnyen megáshatja a vállalat sírját. A makrogazdaságban pedig a gazdaságpolitika és a gazdaságszabályozás késlekedései, bizonytalanságai kényszeríthetnek ki olyan kiigazításokat, amelyek ráfordításigénye egy korai és határozott beavatkozáshoz képest annak többszöröse.

5. Optimális idôpont az a kizárólagos időpont, amelyben minimális ráfordítással maximális eredményt lehet elérni. Ilyen idốpont lehet például egy új gyártmány vagy szolgáltatás jól idôzített kifejlesztése és piaci bevezetése. Újabban fóként a nagyrendszerek, így a komplex fejlesztési, termelési és értékesítési hálózatok múködtetésében nốtt meg erôteljesen az optimális időpont megválasztásának jelentősége.

6. A kizárólagos idó azt az egyetlen idópontot jelöli, amelyben még el lehet hárítani egy fenyegetést, 
vagy még ki lehet használni egy lehetőséget. A küszöbön álló fenyegetés elhárítására vállalati példa a radikális karcsúsítás vagy a vagyon egy részének értékesítése a csőd és felszámolás elkerülésére.

7. A fogyó idố azt a korlátozott időintervallumot jelzi, amelyik még rendelkezésre áll a jelen és a kizárólagos idő között. Fogyó idő áll például a vállalatvezetés rendelkezésére, hogy megkísérelje a megegyezést munkatársaival egy már bejelentett sztrájk előtt.

8. Az irányváltó idó fogalma azt jelzi, hogy egy gazdaság vagy vállalat múködésében, verseny- és/vagy háttérkörnyezetében gyorsulásból lassulásba vagy lassulásból gyorsulásba vált át az idő üteme.

9. Ehhez kapcsolódik az ütemküszöböt átlépó idő fogalma: ez azt jelzi, hogy az idô iránya (tehát a gyorsulása vagy a lassulása) nem változik, de a változás mértéke meghalad egy olyan kritikus értéket, amely már fenyegeti akár egy gazdaságpolitika, akár egy üzleti stratégia alapvetố céljait.

10. A jelenérték ideje (mint közismert) azt érzékelteti, hogy egy jövőben létrejövő ráfordításnak, eredménynek vagy értéknek várhatóan mekkora ráfordítás, eredmény vagy érték felel meg a jelenben. Ennek segítségével elemezhetốk például a különbözô makro- vagy mikroszintú finanszírozási tranzakciók, beruházási lehetôségek stb.

11. A feladatfüggó́ idố azt fejezi ki, hogy különbözô feladat- vagy munkakörökhöz más és más időérzékkövetelmény kapcsolódik. Jelentősen felgyorsulhat például az idő egy stratégiai, azaz hosszú időtávú kérdésekkel foglalkozó menedzser számára, amikor átveszi a vállalat operatív múködésének irányítását. Vagy ugyanígy gyorsul fel az idő a kormányzás szférájában, például amikor az a vezetô, aki korábban az apparátus irányításában vett részt, kormánybiztosi kinevezést kap. Az idő feladatfüggő követelményének mérlegelése és az egyén képességeinek ezzel való szembesítése egyre fontosabb szempontja lett az utóbbi években a munkaerô-felvételnek, az áthelyezéseknek, a magasabb beosztásba való kinevezéseknek stb.

12. Végül sajátos a motivációs idó fogalma. Ez nem csupán azt fejezi ki, hogy az egyén ,időtudata” és időértékelése függ egy tárgyilagos és egyre nagyobb teljesítményre sarkalló jövedelemelvonási-átcsoportosítási, illetve vállalati motivációs rendszertól. A fogalomba az is beletartozik, hogy az egyén időfogalma szubjektív motiváltságának és az ebben szerepet játszó tényezóknek - tehát például hangulatának, élményeinek, tájékozottságának, közérzetének, a munkatársaival és vezetôivel való jó vagy rossz kapcsolatának stb. - is a függvénye.

\section{Az idô vállalati gyorsításának és lassításának ellentmondásai}

Az elmúlt évek-évtizedek tapasztalata szerint világszerte két tényező́csoport hatására gyorsultak fel a gazdálkodó szervezetek verseny- és háttérkörnyezetének eseményei. Az egyik a müszaki fejlódés volt, s ez megjelent a felhasznált anyagokban, az alkalmazott technológiákban, a termékekben és szolgáltatásokban, valamint ezek felhasználásában egyaránt. A másik tényezócsoport a kiteljesedó globalizáció volt a maga vállalati szerkezetével, ${ }^{10}$ valamint jogi, pénzügyi, közlekedési/szállítási és informatikai ,infrastruktúrájával”. És ez a felgyorsulás olyan hatalmas kihívást jelentett a vállalatok számára, hogy válaszul sokszor átformálták egész üzletpolitikájukat, szervezetüket, múködésüket és irányítási rendszerüket. A jelentősebb válaszlépések, valamint ezek idốt gyorsító vagy lassító hatása a következókben foglalható össze:

- A nagy- és óriásvállalatok egyik meghatározó törekvése korunkban a tókekoncentráció. S erre nem csupán (sốt nem is elsôsorban!) a nyereség növelése készteti a vállalatokat. Tókekoncentráció nélkül ugyanis aligha tudnának részt venni a múszaki fejlesztés egyre gyorsuló, mind élesebb, és egyre nagyobb erőforrásokat igénylő versenyében. Arra sem lennének képesek, hogy a globális színtér számos pontján egyszerre (vagy legalábbis idejében, a konkurensek megjelenése előtt) hozzák piacra új termékeiket, ami viszont jelentős potenciális piacok elvesztésével járna. A piaci bevezetések szétforgácsolásával pedig elmulasztanák a nagyságrendi megtakarítás lehetôségének kihasználását is. Végül mindezzel vészesen csökkenne a biztonságuk is, hiszen nem tudnák megosztani értékesítésüket (vagy akár termelésüket is) olyan országok között, amelyek gazdasági folyamatai más feltételektől függnek és/vagy amelyek gazdasága ugyanazokra a hatásokra másként reagál. A tókekoncentrációnak pedig hármas, és részben ellentétes hatása van. A növekedés hatására ugyanis lemerevednek egyes vállalati folyamatok - elsôsorban az egyre összetettebb, bonyolultabb termelési folyamatok. Más vállalati tevékenységek viszont $\mathrm{fel}$ gyorsulnak - példa erre a kutatás és fejlesztés, amelyik az időben és diffúziójában is gyorsul. S végül a felgyorsult vállalati folyamatok számottevően $\mathrm{fel}$ is gyorsítják múszaki, gazdasági és társadalmi környezetük eseményeit, ami viszonylagosan lassítja saját múködésük ütemét. Vagyis ezek a vállalatok önmagukat manóverezik bele egy ördögi körbe, amelyben mind élesebb lesz múködésük felgyorsulásának és lemerevedésének az ellentmondása. 
- A vállalatok kutatás-fejlesztési versenyében - amelyik a legnagyobb és legtartósabb versenyelónyök egyikét adhatja meg számukra - nem csupán a tôkekoncentráció teremtheti meg a mind nagyobb forrásigény fedezetét. Ez elérhetô a fejlesztés, majd ennek eredményeire alapozva a beszerzés, a termelés és az értékesítés koncentrálásával is. A távlati versenyképességet is szem előtt tartó koncentrálás a vállalati profil leszúkítése a magkompetenciára (a „,core competence”-re). ${ }^{11}$ Ez a profilszúkítés azonban felértékeli a beszállítói kapcsolatokat, hiszen az „,integrátor vállalat” teljesítménye annál inkább függ ezektôl, minél jobban összpontosítja tevékenységét a magkompetenciájára. A kapcsolatok erósítésére, szorosabbra fúzésére pedig hosszú távra tervezett beszállítói kapcsolatokat építenek ki: így jönnek létre az egyre komplexebb beszerzési, termelési és értékesítési hálózatok vagy klaszterek. És ezek nemcsak a termelési-szolgáltatási folyamatok rugalmasságát növelik, hanem azok múködését is felgyorsítják, sốt még a költségeit is csökkentik. Mindennek azonban ára van: egy magkompetenciára zsugorított klaszterprofil ugyanis az „egy lábon állás” veszélyével jár - vagyis a gyorsulás, a rugalmasságnövelés és a költségcsökkenés előnye a nagyobb üzleti kockázat hátrányával párosul. És különösen megnő a beszállítók kockázata, ha az integrátor vállalat - üzleti érdekére hivatkozva - profilt, telephelyet és/vagy piacot vált, s ók akár máról holnapra hoppon maradnak. Ez tehát a vállalati múködés gyorsulása és az annak kockázata között kialakuló ellentmondás mind az integrátor vállalat, mind a beszállítók számára. $\mathrm{S}$ ezért kívánatos, hogy a vállalati múködés klaszterekkel elérhetô gyorsításának és eredménynövelésének elónyeit valamennyi partner a számára és a klaszter egésze számára még vállalható bizonytalansággal súlyozva mérlegelje.

- Számottevően gyorsíthatja fel az időt egy vállalat múködésében, ha konkurensével stratégiai szövetséget köt. A kutatás és fejlesztés területén kötött stratégiai szövetség például csökkenti a kutatás és fejlesztés időigényét (hiszen segítségével megnő a kutatási kapacitás) ezzel megteremti a lehetôséget, hogy a fejlesztés eredménye korábban jelenjék meg a piacon; a szövetség megosztja az innoválás vállalati költségeit, tehát kisebb lesz a fajlagos ráfordításigény; végül kiküszöböli azt a veszélyt is, hogy a most már szövetséges konkurens önálló fejlesztóként esetleg learassa a lehetséges árbevétel oroszlánrészét, mert korábban készült el saját fejlesztésével. Az ilyen stratégiai szövetség felgyorsítja a vállalati folyamatokat - ám a verseny tompításával lassítja a piaci folyamatokat. ${ }^{12}$ És ugyanez a piaci következménye annak, ha két vagy több vállalat gyártmányszerkezetének megosztásáról köt stratégiai szövetséget. Ez tehát a vállalatok múködési idejének gyorsulása és a piaci folyamatok lassulása között létrejövő ellentmondás. (Mindezzel kapcsolatban azonban meg kell jegyeznünk: számos kis- és középvállalat számára a stratégiai szövetség a túlélés egyetlen lehetősége, mert csak ennek segítségével maradhatnak talpon a nagy- és óriásvállalatokkal szemben. Vagyis a kis- és középvállalatok ilyen stratégiai szövetségei éppen, hogy nem lassítják le a piaci folyamatokat, hiszen erôsítik a versenyt.)

- Nem újdonság, hogy számos elônnyel jár a nagy- és óriásvállalatok számára, ha kiterjesztik tevékenységüket a világ mind több országának piacára. Ezzel nagyságrendi megtakarításokat érhetnek el, és felgyorsíthatják befektetéseik megtérülését is; növelhetik biztonságukat azzal, hogy egyes piacaik - mint említettük - más hatásokra más időben és másként reagálnak; kitelepíthetik termelő és/vagy szolgáltató tevékenységüket kedvezôbb feltételeket kínáló országokba, amivel nemcsak költségeiket csökkenthetik, hanem könnyen és gyorsan új piacokra is szert tehetnek stb. Van azonban a globális színtéren való megjelenésüknek még egy újabb, a vállalati múködésüket felgyorsító hatása is: ez a „korszerúségi lépcsók” előnyének globális méretû kihasználása. A világpiacon jelen lévő vállalatok ugyanis áttelepíthetik a legfejlettebb gazdaságok piacain már korszerütlenné váló termékeiket és gyártási technológiájukat a kevésbé fejlett országokba, hogy ezzel meghosszabbítsák jövedelemtermelő képességüket - s hogy az így létrehozott jövedelemtöbbletet új gyártmányaik és új technológiáik kifejlesztésének és bevezetésének felgyorsítására fordítsák. Így kapcsolódik össze a „globális vállalatok” üzleti stratégiájában a fejlesztés gyorsítása az igénytelenebb piacok meghódításával, méghozzá ezeken olykor az igényesség, vagyis a vásárlóerố növelésének visszafogásával (a munkabérek alacsony szinten tartásával, a belső elszámoló árak torzításával stb.). Ez tehát a vállalati folyamatok gyorsulásának és a piaci igényszintnövelés lassításának az ellentmondása.

- Aligha van olyan megoldás a vállalatok múködési idejének felgyorsítására, amelynek kisebb lenne a forrásigénye, mint a szervezetfejlesztésnek. Ennek legkézenfekvóbb módszere a „,vattaemberek” elbocsátása. Egy hosszabb távon sikeres vállalatnál azonban már aligha vannak ilyenek. Ezért a szervezetfejlesztés föként a folyamatok újjászervezését (ez a reengineering, amelynek azért számottevố beruházási feltétele, tehát forrásigénye is lehet!), vagy a szervezeti struktúra átalakítását jelentheti. Az utóbbi irányadó szempontja, hogy az új szervezetek rugalmasabban alkalmazkod- 
janak a környezeti feltételekhez, és ennek érdekében gyorsuljon fel a múködésük. Erre napjainkban leginkább két megoldással törekszik a vállalatok vezetése: a múködés decentralizálásával és az információáramlás akadályainak felszámolásával. A decentralizálás lényege, hogy multidiszciplináris ${ }^{13}$ és önálló döntési jogkörrel rendelkező szervezeteket (divíziókat, munkacsoportokat - vagyis teameket, feladatcsapatokat, azaz task-force-okat és projektszervezeteket) hoznak létre azoknak a tennivalóknak az elvégzésére, amelyekkel a vállalat gyorsabban és hatékonyabban elégítheti ki környezetének igényeit. Az információáramlás akadályait pedig fóként a „funkcióhatárok légiesitésével" bontják le: ezzel teszik lehetővé a közvetlen információcserét a vállalat bármelyik két munkatársa között, azzal a megkötéssel, hogy annak eredményéról haladéktalanul tájékoztatniuk kell vezetôjüket, s akinek mindez nem csorbítja a döntési jogkörét. A vállalati múködés gyorsítása akár decentralizálással, akár a funkcióhatárok lebontásával jelentősen növelheti a vállalat versenyképességét - de mindkét megoldásnak hátrányai is vannak. A decentralizálás a vállalati önazonosság, kultúra, arculat és kommunikáció (a „,core values”, a „,corporate culture”, a „corporate image” és a „,corporate communication”) egységének, valamint a múködés szinergiakövetelményének érvényesülését fenyegeti - márpedig ezek egyre nagyobb szerepet kapnak a fejlett piacok egyre élesebb versenyében. A funkcióhatárok lebontása pedig akaratlanul is csökkenti a csúcsvezetố koncepcióinak egyértelmúségét és súlyát a vállalati funkciók és hierarchiaszintek öszszességében mint „információs vételkörzetben”. Így alakul ki az ellentét a vállalati múködés szervezetfejlesztéssel elért gyorsulása és az egész szervezet múködésének egységes célra irányítása között: ez a múködési idő gyorsításának a részoptimumok és a „,vállalati egész" optimuma között létrejövő ellentmondása.

- A vállalati múködés felgyorsításának hatékony eszköze a humáneróforrás-menedzsment. Ezzel szemben a legnagyobb kihívás, hogy a stratégia idôtávjában kell összhangba hozni a stratégiai feladatokat és a humán erőforrás felkészültségét. Gyorsan változó világunkban ez három követelményt állít fel: vezetốk és munkatársak vállalják és valósítsák meg az élethosszig való tanulást; tartsák munkakörükben napi feladatuknak a „kreatív készenlétet”; s végül a vállalat vezetése helyesen jelölje meg a tovább- és átképzési célokat, jól válassza ki a képzésekben részt vevő munkatársakat, és biztosítsa megszerzett tudásuk széles körú transzferjét a vállalatban. Az utóbbi esetében a menedzsmentnek azzal kell számolnia, hogy nem gyorsítani, hanem lassítani fogja a vállalat mú- ködését, ha kiderül, hogy rosszul jelölte ki a továbbés átképzés céljait, mert a fejlődés más irányt vett; ha olyan munkatársakat választott ki a képzésben való részvételre, akik az új ismeretek elsajátítására és/ vagy átadására alkalmatlanok; vagy ha nem tudta jól megszervezni a tudástranszfert a vállalatnál. Ezért a humánerôforrás-menedzsment a gyorsítás nélkülözhetetlen, de - különösen felgyorsult világunkban - nagyon is ellentmondásos eszköze, amellyel egy vállalat vezetése eredeti céljának könnyúszerrel éppen az ellenkezójét érheti el.

- Végül kifejezetten a széles piacra termelô, és azon értékesítő kis- és középvállalatok nagy problémája múködésük jelentős felgyorsítása, hiszen éppen ezek ,célterületein”, piaci rések (amelyekre a nagyvállalatoknak nem kifizetôdő betörni a kereslet kis volumene miatt) nyílnak és zárulnak egyre gyorsabban. A rések változásaihoz úgy alkalmazkodhat sikeresen egy kis- vagy középvállalat, ha érzékeny információs rendszert fejleszt ki, és igen rugalmassá alakítja fejlesztési, termelési (szolgáltatási) és értékesítési tevékenységét. A rugalmasság létrehozását azonban többnyire megakadályozza a forrásainak szúkössége: az átlagos kis- és középvállalatok általában sem elég időt, sem elég pénzt nem tudnak kigazdálkodni egy „real time” piaci információs rendszer, valamint a munkatársak életútjának egészét átfogó tanulás ráfordításainak fedezésére. Ezért könnyen lehet, hogy a gyorsulás kihívására egy kisvagy középvállalat nem tud megfelelően válaszolni, ami elóbb-utóbb múködésének lelassulásához, végsô soron a vállalat csődjéhez vezet. Ez jellegzetes példa a felismert gyorsulási feladatok és az azok megvalósítását megakadályozó folyamatos forráshiány ellentmondására.

Mindezzel szemben kevésbé ellentmondásos az a helyzet, amely egy vállalat múködésének lassulása nyomán alakul ki. Maga a lassulás bekövetkezhet vállalati belső, azaz szervezeti, múködési vagy irányítási okokból éppúgy, mint a verseny- vagy a háttérkörnyezet folyamatainak és eseményeinek hatására. Ezek közül egy vállalat számára azok a legveszélyesebbek, amelyek csak saját múködését érik, vagyis nem hatnak a versenytársaira. Ilyen lassulás következhet be például a túlságosan hierarchizált vállalati szervezet, egy téves nagyberuházás, a termelési folyamatban kialakuló üresjáratok, a lassú információs vagy a tompa érdekeltségi rendszer miatt - vagy pusztán azért, mert a vállalat elöregedett, és szinte már csak rutinból múködik. Az egyetlen vállalatra korlátozódó lassulás tehát csökkenti annak versenyképességét, $s$ végül a csődjét, majd felszámolását is előidézheti. A lassulásokkal kapcsolat- 
ban az alapprobléma mindig háromfázisú: az a kérdés, hogy a vállalat vezetése idejében számolt-e a lassulást kiváltó folyamatok és események bekövetkezésével, hogy felkészítette-e és jókor a szervezetet a lassulásra, és hogy késedelem nélkül meghozta-e a szükséges intézkedéseket a lassulás kivédésére, vagy legalábbis hatásának számottevő csökkentésére? S napjaink gyors változásai közepette ezek közül már az egyik kérdés nemleges megválaszolása is elegendô ok arra, hogy a tulajdonos vagy képviselôje joggal vonja meg bizalmát a vállalat menedzserétól. - Relatív lassulás esetében nyilván az az elsố számú vezetố legfontosabb feladata, hogy mielóbb felgyorsítsa a vállalat múködését. Erre alkalmazhat olyan drasztikus eszközöket, mint a pályamódosítás vagy a pályaváltás, a cég profiljának módosítása, vagy a vagyon egy részének értékesítése, hogy ennek vételárából korszerúsítse a termelési és irányítási folyamatokat, s így állítsa talpra a vállalatot. ${ }^{14}$ De ha idejében intézkedik, akkor még „szoftvereszközökkel” is helyreállithatja cégének versenyképességét: karcsúsíthatja, átszabhatja szervezetét, új értékrendet és ösztönzési rendszert vezethet be, decentralizálhatja vagy új kontrollingrendszerek támogatásával éppen, hogy centralizálhatja az irányítási rendszert stb.

A vállalati múködés lelassulásakor végül is két nagy ellentmondás jöhet létre. Az egyik, hogy nem állnak a vállalat rendelkezésére a múködés felgyorsításához szükséges eróforrások. Ez a probléma akkor hidalható át könnyebben, ha a vállalatnak van meggyőző terve a gyorsításra és a gazdasági háttérkörnyezet szereplőinek pedig hitelezési forrása a megvalósítás finanszírozására. A másik ellentmondás a felgyorsítás tennivalói és a menedzser magatartása között alakulhat ki: nevezetesen akkor, ha a vállalat vezetôje - mintegy önmaga igazolására - késốn vagy egyáltalán nem hozza meg a felgyorsításhoz szükséges döntéseket. Ilyenkor nem csupán a vezetô leváltása következhet be, hanem - veszélyhelyzet kialakulása esetén - válságmenedzser megbízására is sor kerülhet.

\section{Időtípusok, idôtípusváltások}

Az időtípusok sajátosságai és problémái jól érzékelhetók a vállalatok környezetükkel való kapcsolatában: ahogy vezetésük viszonyul a múszaki fejlődés irányzataihoz, a versenyhelyzet és a kockázat alakulásához, a gazdaságpolitika és -szabályozás rendelkezéseihez és végső soron a globalizáció folyamataihoz. Ezeket tekintjük át a következókben.

- A múszaki fejlódés világméretú trendjének megvalósulása áll - mint már említettuik - legközelebb az objektív és tárgyszerú idôtípus fogalmához. Egy adott múszaki terület szakemberei ugyanis ismerik az alapkutatások irányát, ezek már elért és még várható eredményeit, mindezekből következtethetnek a kutatási eredmények megjelenésére termékekben és technológiákban, és innen már csak egyetlen - igaz, csöppet sem könnyú - lépés az innovációk piaci megjelenésének időpontját, helyét és volumenét prognosztizálni. A menedzser a múszaki fejlődés és fejlesztés folyamatának felvázolására külsô szakértők segítségét is igénybe veheti, akik a Delphimódszer segítségével készíthetik el prognózisukat. A módszer lényege: a vállalat vezetôje szakértőket kér fel, hogy lépéssorozat keretében egyeztessék felismeréseiket és következtetéseiket az adott témában, s így jussanak el a „legvalószínúbb jövő” előrejelzésének közös és már egyetértést jelzô megfogalmazásáig. A Delphi-módszer keretén belül jól alkalmazható a korábbiakban már említett WARD ${ }^{2}$ technika. Ezt követóen, és már a vállalat keretében, a termelés és a marketing szakembereinek a feladata, hogy közösen kíséreljék meg prognosztizálni az innovációk megjelenését a piacon. Álláspontjuk kialakítását az átálláselemzés (,Switching Analysis”) módszerének alkalmazása segítheti. Ezzel azt mérik fel, hogy mekkora ráfordítással és veszteséggel jár az átállás, illetve hogy hol, milyen áron és milyen volumenben értékesíthető az innováció - vagyis összességében mekkora eredménynövelésre és piaci pozícióváltozásra számíthat a vállalat. Ebból a két elôrejelzésbő́l következtetéseket vonhat le a vállalat vezetése mind a stratégia, mind az operatív irányítás idôtávjában. A Delphi-módszerrel kapott eredményeket a menedzsment fóleg a hosszú távú fejlesztések témáiban - a profil- és piacszerkezeti módosítások, a nagyberuházások, valamint a tovább- és átképzési feladatok stb. eldöntésében - hasznosíthatja, mert azokban akár egy kvázi-objektív és tárgyszerú időt is számításba vehet. (A Delphi-módszer végeredményének ugyanis tartalmaznia kell az elöre jelzett trend bekövetkezésének valószínúségét is. És ha ennek értéke közel áll az 1,0-hez, a stratégia objektív és véletlenszerú idôtípusa kvázi-objektív és tárgyszerú idôtípusként értékelhetoo.) $\mathrm{Az}$ átálláselemzés eredményei viszont elsősorban a késóbb sorra kerülő operatív döntéseket készítik elő. Ezeknek - a sokszor váratlan befolyásoló tényezók miatt - már jóval nagyobb a bizonytalansága: prognózisukban - a szakemberek egyéni megítélései miatt - a szubjektív és véletlenszerú időtípus jelenik meg a menedzser számára. Ezért a múszaki fejlődés átfogó témakörében az a döntést hozó feladata, hogy az innovációk piaci megjelenéséhez közeledve meg-megismételtesse az átálláselemzés 
eredményeinek felülvizsgálatát, s így közelítse fokozatosan időtípusukat a kvázi-objektív és tárgyszerú idôtípushoz. Minél inkább közeledik ugyanis egy múszaki innovációs ötlet termékként vagy technológiaként a piaci megjelenéshez, annál egyértelmúbb lesz, hogy milyen ütemben változik (gyorsul vagy lassul) a megjelenésig még hátralévő idô, s hogy miként szúkuül a menedzsment mozgástere, ha sikerrel kíván válaszolni az innováció kihívására. S ebből következik témánk szempontjából egy elméleti megállapítás: a menedzser feladata, hogy az idő múlásával mintegy átlépjen az egyik időtípusból egy másikba - ami az idő gyorsulásának és lassulásának, valamint az üzleti kockázatnak a megítélését is befolyásolja.

- Versenyhelyzetben kemény tények feszülnek egymásnak: elsősorban a vevoók fizetôképes kereslettel alátámasztott igényei, a versenytársak és a saját vállalat kínálata - az utóbbiak mögött pedig a vállalatok minden erőforrása (beleértve ebbe szervezetüket épp úgy, mint múködésüket, irányításukat, immateriális erőforrásaikat stb.). Ezek felmérése és összevetése a szokásos kétirányú, vállalatot vállalattal összemérố benchmarking újabb változatának, a háromirányú benchmarking technikának a feladata. Ez két konkurens vállalat „paramétereit” a vevőigények ismeretében súlyozza. A technika alkalmazása hozzásegítheti a vállalat vezetôjét, hogy értékelésében, vagyis a versenyhelyzet jelenében egy kvázi-objektív és törvényszerú idốt érzékeljen. A menedzsernek azonban azt a hatást is figyelembe kell vennie, amelyet a háttértényezók váltanak ki. S ezek számbavétele csak az objektív és véletlenszerú időtípusban történhet. Mert igaz, hogy a háttértényezók kemény feltételeket teremtenek, de bekövetkezésük időpontja bizonytalan: ez éppúgy függ kérlelhetetlen gazdasági tényektól, mint a gazdaságpolitikai és -szabályozási szándékoktól. A vállalat vezetôje azonban még ennek az objektív és véletlenszerú időtípusnak a kockázatát is csökkentheti a benchmarking technika továbbfejlesztett változatával, a Benchmarking EFC-vel (ez a „Benchmarking Extended by Flexibility Checking"): ez a versenytársvállalatok rugalmasságát, annak mértékét és természetét is értékeli. Vagyis egy jól kiválasztott vezetési technika - illetve egy jól ismert technika továbbfejlesztése - kedvezóen módosithatja a menedzsment számára a döntéseket befolyásoló időtípust. A vállalat vezetôjének azonban nem csupán a jelen versenyhelyzetét kell átlátnia. Versenystratégiájában több olyan pályát kell számításba vennie, amelyeket végigjárva vállalata javíthat versenypozícióján, vagy azt legalább megórizheti. Az optimális pálya kiválasztását - mint közismert - a szcenáriókat felállító és a bekövetkezésük valószínú- ségét jelző döntés-elôkészítés segítheti. S ebben ismét a szubjektív és véletlenszerú idő sajátosságai jelennek meg, amelyeket a döntés-előkészítés újabb és újabb megismétlése közelítheti mindinkább az objektív és véletlenszerú idő jellegzetességeihez. Megjegyezzük: különleges, és napjainkban egyre gyakoribb probléma ebben a tárgykörben a fejlesztési lépcsóket átugró versenytárs megjelenése. A felgyorsuló idő ugyanis egyre több lehetôséget teremt arra, hogy egy követő (és elsôsorban a múszaki élvonalat követô) vállalat átugorjon fejlesztési lépcsôket. Így számottevően lerövidítheti önmaga számára a korábban mások által már végigjárt fejlődési pályát. ${ }^{15} \mathrm{~S}$ ezzel nem csupán hozzájárul az idő gyorsításához, hanem váratlan és veszedelmes versenytársa is lesz az élvonalbeli vállalatoknak, hiszen megtakarította a kutatás-fejlesztési költségek nagyobb hányadát, s ezért a konkurensekénél jóval alacsonyabb árakkal tud részt venni a versenyben. Az ilyen vállalatok megjelenését szintén a Benchmarking EFC technika jelezheti elôre úgy, hogy látókörét a követő (tehát nem közvetlen versenytárs) vállalatokra is kiterjeszti. A fenyegetett vállalatok ilyen vizsgálatokkal közelebb juthatnak a „kvázi-obejktív és törvényszerü” időtípushoz, így növelhetik meg reakcióidejüket, vagyis lassíthatják le önmaguk számára a váratlanul felgyorsuló időt. A menedzsernek azonban el is kell indítania vállalatát a legvalószínúbb szcenárióban megvalósítható optimális pályán. Ekkor pedig a szubjektív és törvényszerü idő szabálya szerint kell kitúznie a feladatokat a vállalat egyes szervezeti egységei számára. A versenyhelyzet példájából leszúrhető tehát egy újabb elméleti következtetés: a vállalatvezetés tevékenységének folyamatában sokszor szükségszerüen követik egymást az időtípusváltások, s az ilyen váltások elmulasztása vagy késleltetése csökkenti a menedzsment hatékonyságát.

- A piaci versenynek azonban nem csupán a konkurens vállalatok és a vevók a szereplói: ezek közé tartoznak - és a klaszterek jelentőségének fokozódásával egyre nagyobb súllyal - a vállalatok partnerei is, vagyis a beszállítók, az értékesítók, a számukra szolgáltatásokat végzók. Általános a tendencia, hogy a pillanatnyilag kedvezô partnerkapcsolatokhoz képest felértékelődtek a hosszú távú kapcsolatok. Már kevésbé az a meghatározó szempont tehát, hogy például melyik beszállító kínálja pillanatnyilag jobb paraméterekkel, rugalmasabb szállítási idókkel és olcsóbban a keresett alkatrészt vagy részegységet a végtermék gyártójának. Inkább az nyom a latban, hogy a beszállító évek hosszú során át lépést tud-e majd tartani a megrendelő fejlesztéseivel és egyre magasabb minôségi és/vagy korszerúségi követelményeivel. Régebben tehát a pontosan számításba vehetô előnyök és hát- 
rányok határozták meg a partnerkapcsolatokat, méghozzá a potenciális partnerek viszonylag jól körülhatárolható körén belül. Vagyis a partnerek kínálatai a kvázi-objektív és törvényszerú időtípusban érkeztek be a vállalat vezetôjéhez. Újabban viszont nagy szerepet kap a jóval szubjektívebb, és ezért bizonytalanabb megítélés: vajon a globális színtéren már aligalig átlátható „tengernyi” potenciális partner közül a végül számításba vett partnerek miként tudnak majd lépést tartani a megrendelő vállalat fejlődésével, fejlesztéseivel? Egy ilyen döntés pedig már a szubjektív és véletlenszerú időtípus körébe tartozik. Ebból a példából ismét következik egy elméleti megállapítás: az időhorizont kiterjesztése indokolhatja, hogy a menedzsment a legbiztosabb objektív és törvényszerü időtípustól távolodó, kisebb biztonságot adó időtípus szabályai szerint értékeljen és hozza meg döntését. Ezzel szemben a nagyobb biztonság választásával bekövetkezhet, hogy egy távolabbi jövőben az idő egyszer csak vészesen felgyorsul cége számára, és vállalata hirtelen légüres térben marad a magkompetenciájával, mert kiderül, hogy partnere a klaszterban már nem képes lépést tartani vállalatának legújabb fejlesztéseivel. - Egy klaszteren belül pedig különösen a bolygóvállalatok ${ }^{16}$ válnak sebezhetôvé, hiszen akár egyetlen téves fejlesztési döntés egész egzisztenciájukat veszélyeztetheti a késóbbiekben. (Az integrátor nagyvállalat ugyanis könnyebben vészeli át egy téves fejlesztési-beruházási döntés következményeit nagyobb eróforrás-volumenével, többnyire szétágazó profiljával, szélesebb és differenciáltabb piacszerkezetével.) Az általános gyorsulásban rejlô veszélyt, s ebben az objektív és véletlenszerú idô megjelenését két, egymást nem kizáró megoldással csökkenthetik a bolygó-, illetve a beszállító vállalatok. Vagy az integrátor vállalattal szoros összhangban fejlesszék erőforrásaikat, múködésüket és irányítási rendszerüket, arra is törekedve, hogy az integrátor minél több telephelyén, minél több külföldi vállalatrészénél legyenek beszállítók. Vagy hozzanak létre egy újabb gyártási-szolgáltatási profilt is - lehetôleg olyat, amelynek termékeit és/vagy szolgáltatásait már nem beszállítóként, hanem közvetlenül a széles piacok vevőinek értékesíthetik.

- Az idő gyorsulása és lassulása összefügg a kockázattal is. A gyorsuló idó általában megnöveli a kockázatot azzal, hogy élesedő versenyhelyzetben nagyobb a lemaradás veszélye; hogy a felgyorsulás beszúküló idôtávjában sưrúsödik mind az operatív cselekvések, mind a stratégiai változatok lehetôsége ${ }^{17}$; $\mathrm{s}$ végül azzal, hogy ilyenkor lerövidül a ráfordítások megtérülésének ideje. Vagyis az idő gyorsulásával együtt nő a kockázat is, és ebben ismét az idő kvázi-objektív és törvényszerü sajátossága jelenik meg. Egy vezetố magatartását és döntéseit azonban nem csupán a kockázat nagysága, hanem önmaga és az irányított szervezet kockázatviselő képessége is befolyásolja. A felgyorsuló idő tehát szembesítheti a vezetôt egy akkora kockázattal is, amekkorát már nem vállal. (Erre lehet példa egy olyan helyzet, amelyben a vállalat - hogy növekedjék a piaci biztonsága - két profilban, vagyis két termelési területen múködik. Ám ennek következtében kétfelé kell osztania fejlesztési forrásait, s ez hátrányt jelenthet az „egyprofilú” vállalatok fejlesztési lehetőségeivel szemben. A vezetés azonban nem vállalja ebben a helyzetben az egyik profil felszámolásának kockázatát - vagyis nem adja fel a nagyobb biztonságot a vállalat versenyképességének azért az esetleges növeléséért, amely a fejlesztési források egyetlen célra való fordításának lehet az eredménye. ${ }^{18}$ ) Ilyenkor áthidalhatatlan lesz a távolság a konkrét megjelenésében objektív és véletlenszerú idôtípus követelményei és a vállalatnál kialakított tervek és múködési folyamatok szubjektív és törvényszerú időtípusának lehetôségei között. A menedzser az időtípusoknak ezt az ellentmondását előzetes felkészüléssel kerülheti el: fel kell vérteznie szervezetét a nagy kockázat objektív és véletlenszerü megjelenésére. Ehhez azt a szubjektívés törvényszerü idôtípust, amelyben vállalata múködik, szubjektív és véletlenszerú típussá kell átalakítania a forrásfelhalmozás területén: másként fogalmazva, akkora eróforrásokat kell felhalmoznia a vállalatnál, amelyekkel el tudja majd hárítani a kockázat objektív és véletlenszerü idôtípusában bekövetkezô fenyegetéseket. Ennek technikája a „kockázatorientált forrásfelhalmozás” (a „Risk-oriented Resource Accumulation”). Alkalmazása nem könnyú napjaink élesedő versenyfeltételei között, amikor majdhogy minden eróforrás bevetésére szükség van ahhoz, hogy egy vállalat növelje, vagy legalább folyamatosan megórizze a versenyképességét. Ezért lett az RRA-technika velejárója a „kegyetlen költségcsökkentés” és a „kíméletlen karcsúsítás". S mindebból ismét levonható egy elméleti következtetés: egy célszerú idôtípusváltás olykor csak jelentôs erôforrás-áldozattal valósulhat meg - s ezért van szükség ilyenkor egy igen körültekintő költség-/haszonelemzésre, méghozzá olyanra, melynek ,indexében” a SWOT-elemzés (p,f,r) szempontjai szerepelnek (vagyis ezt az elemzést is az index három „metszetében” célszerü elvégezni).

- A gazdaságpolitika és gazdaságszabályozás többnyire kemény feltételrendszert szab a vállalatok számára, $\mathrm{s}$ a beépített szankciók miatt egyértelmúen az objektív 
és törvényszerú idôtípust jeleníti meg a menedzsment számára. Ez azonban - mint említettuik - csak rövid távon igaz: a gazdaságpolitika és -szabályozás célja és eszközrendszere változik, s ennek a módosulásnak sem a tartalma, sem az idôpontja nem egyértelmú. Hosszabb távon tehát az objektív és törvényszerú időtípus az objektív és véletlenszerú idôtípusként jelenik meg. Márpedig alapvetően fontos lehet egy vállalat számára annak elôrejelzése, hogy mikor és hogyan (vagy legalábbis milyen irányban) módosulhat a gazdaságpolitika preferenciasora, valamint az üzleti tevékenység szabályozása. A változásoknak a kormányzatok saját elôrejelzéseinél többnyire megbízhatóbb támpontja a gazdaság- és konjunktúrakutató intézetek elôrejelzése, a bevezetốben már említett STEEPLEelemzés, valamint a gondolatmenetünk végén szereplô hármas tükörmodellre alapozott vizsgálat. A vállalati körben végzett két utóbbi elemzés sok tényezóje számszerú és konkrét - például a gazdasági növekedés, a foglalkoztatás aránya vagy az inflációs ráta alakulása. Más tényezók azonban az egyéni megítélés kategóriájába tartoznak - ilyen például az innovációs készség és képesség intenzitása. Ezért jut nagy szerep ebben a két elemzésben a szubjektív és véletlenszerü időtípusnak. Ennek érvényesülését azonban célszerú a minimumra korlátozni, amit a bipoláris szcenárióelemzés (a „Bipolar Scenario-analysis”, BSA) alkalmazása könnyíthet meg. A BSA azt írja elő, hogy a vállalat vezetôje kérjen fel a politikai élet két vezetô pártjának (vagy pártcsoportjának) gazdaság- és társadalomfilozófiáját valló, de szakmailag nem elkötelezett szakértóket a várható gazdaságpolitikai és szabályozási fordulatok előrejelzésére. Prognózisaikat ezután független politológusok és szociológusok észrevételei alapján értelmezze a menedzsment, hogy így fogalmazhassa meg végül a szubjektivitását már helyesbítő vagy kiegészítő előrejelzéseket. A módszer alkalmazásával a menedzser a kvázi-objektív és törvényszerü időtípushoz közelíthet. Példa lehet minderre két olyan prognózis, amelyek közül az egyik (a politológusoké) a kormányváltást, a másik (az ellenzék gazdaságpolitikáját valló gazdasági szakértôk) a kormányra kerülók erôteljes exportösztönző szabályozását prognosztizálják. A két előrejelzést együttesen értékelő menedzsment felgyorsíthatja ezután a vállalati múködés idejét: eróltetett ütemben tárhat fel új exportpiaci lehetőségeket az igények és a versenytársak számbavételétól a legígéretesebb lokális partnerek kiválasztásáig. Mindebbő́l két elméleti következtetés is leszúrhetô: a vállalatvezetés tevékenységében egyszerre is jelen lehetnek különböző időtípusok - és ilyenkor az a menedzser feladata, hogy a szubjektív és véletlenszerû, tehát a legbizonytalanabból mindinkább a legbiztosabb, az objektív és törvényszerú típus felé tolja el az intézkedéseit befolyásoló idố típusát. Ezzel akadályozhatja meg ugyanis, hogy az idô váratlanul, erôteljesen és nagy áldozatokat követelve gyorsuljon fel vállalata számára.

- Az idô gyorsulása vagy lassulása a globális színtér egészén is bekövetkezik. Ennek jellegzetessége, hogy a gyorsulás és a lassulás általában idôeltolódással megy végbe a nagy földrajzi régiókban. ${ }^{1-}$ ${ }^{9}$ Többnyire (de nem kivétel nélkül) a legfejlettebb gazdaságokban, a „mozdonyországokban” kezdődik mind a gyorsulás, mind a lassulás - amelyek azonban nem a fejlettségi lemaradás mértékéhez igazodva jelennek meg a többi régióban és/vagy országban. (Ennek egyik oka, hogy a követó gazdaságokban a gyorsulás vagy a lassulás sokszor jobban igazodik a múködőtóke-beáramlás nagyságához, mint belsố fogyasztásuk vagy exportjuk alakulásához.) A gyorsulásnak és lassulásnak ez az idôkülönbsége nagy lehetőség a globális színtéren jelen lévő vállalatok számára. Ennek segítségével kompenzálhatják ugyanis az egyik régióban bekövetkező gyorsuló vagy lassuló idő hatását egy másik régióban még változatlan idő feltételeivel. És ebben a kompenzálásban segítheti menedzsereiket az objektív és véletlenszerü idô sajátosságainak szem elốtt tartása. - A globális színtéren azonban nem csupán dinamikájában van különbség az egyes régiókban érvényesülő idôtípusok és időértékelések között. Azokban a régiókban, amelyekben értékesebb az idő, felgyorsul a gazdaságok múködése és a társadalom fejlódése - sốt meghosszabbodik a társadalom tagjainak az élete is, méghozzá mind abszolút, mind relatív értelemben. Abszolút értelemben azért, mert a magasabb életszínvonal, a társadalom nagyobb szervezettsége, a jobb egészségügyi ellátás meghosszabbítja az egyén életidejét. Relatív értelemben pedig azért, mert egy fejlett társadalomban az egyén életidejének kisebb részét fordítja ugyanarra a tevékenységre, amelynek elvégzése nagyobb életidőhányadot igényel egy kevésbé fejlett társadalomban. Tegyük fel például, hogy egy új szakma elsajátítása - amire mind nagyobb szükség lesz a felgyorsult múszaki-gazdasági feltételek közepette - három év időtartamú ráfordítást igényel. De ez a három év duplán számít annak, akinek a munkában töltött életideje - kényszerúségból - csak fele a jobb gazdasági/társadalmi körülmények között élő munkában eltöltött életidejének. Az idő nagyobb sebessége tehát - legalábbis ebben az értelemben - „meghosszabbítja az életet”. (Íme, végül még a bevezetôben említett közgazdász is megérti Albert Einstein relativitásel- 
méletének megállapítását idő és sebesség összefüggésérốl!) - A vállalatok vezetése a globális gazdaság folyamatairól üzleti stratégiájának megtervezéséhez szintén az erre szakosodott és többnyire világhírú gazdaságkutató intézetek előrejelzéseiból mint külsố forrásokból tájékozódhat, amikor üzleti stratégiáját tervezi. Ezeket egészíti ki belsố forrásként a hármas tükörmodell globális tényezôket tartalmazó része, valamint a „mozdonyországok - aknamezós országok" gazdasági folyamatainak figyelése. A kutatóintézetek az $S$ időtípus érvényességét sugallják prognózisaikban (amire alapjában véve fel is jogosítja ốket szaktudásuk, eddigi múködésük és széles körben elismert presztízsük), de a globális folyamatok és események számtalan bizonytalansága miatt előrejelzéseik aligha érhetik el ténylegesen ennek az időtípusnak a szintjét. A korábban már említett két belső forrás globális információinak megalapozásához és értékeléséhez viszont már jóval kevesebb szaktudás áll a menedzsment rendelkezésére. Ezekbe tehát már jóval több szubjektív felismerés és megítélés épül be, ezért következtetéseikben a szubjektívés véletlenszerú időtípus érvényesül. A felsorolt három forrás prognózisait azonban ,ütköztetheti” a vállalat vezetôje, hogy elbírálja, az előrejelzések melyik koherens változatát fogadhatja el, melyikre alapozhatja üzleti stratégiáját. Ennek során valamennyire megkérdőjelezi majd a kutatóintézetek prognózisát a belső források információi alapján - ezek előrejelzéseit viszont módosítani fogja a kutatóintézeti prognózisok figyelembevételével. Az eredmény az idôtípusok esetében valahol az objektív és véletlenszerú idôtípusban lesz, hiszen az előrejelzések integrálásában keveredni fog a „kvázi-objektív és törvényszerư”, valamint a „szubjektív és véletlenszerü” időtípusra jellemzô megközelítés. Az előrejelzések összesítése után azonban a vállalat vezetójének nem csupán a stratégiai célokat kell kitúznie, hanem meg kell terveznie a célokhoz vezető utat is. $\mathrm{S}$ ez nem csupán határidók megjelölését követeli meg, hanem azt is, hogy munkatársai a határidók között - mint már szó volt róla - az ezek teljesítéséhez szükséges ütemben hajtsák végre az egyes folyamatokat. Az operatív megvalósítás útjának tervezésében tehát a szubjektív és törvényszerú időtípus jelenik meg. Mindebből ismét levonható egy elméleti következtetés: az üzleti stratégia és az operatív tervezés feladatköreiben egyszerre jelenhet meg több idötípus, és ezek együttesen akár egy új idótípusra is átválthatnak. Ebben az esetben azonban a menedzsernek folyamatosan ellenőriznie kell, hogy nem következtek-e be alapvető változások azokban az időtípusokban, amelyek beépültek az új idôtípusba. Ilyen változás lehet például egy váratlan válság az „aknamezős országok” egyikében, amelyik rövid távon objektív és törvényszerú idôvé változtatja a korábban szubjektív és véletlenszerú idót.

\section{Az idófogalom súlypontjai a vállalati szervezetekben}

A gondolatmenetünk elején felsorolt tizenkét időfogalom közül egyesek súlypontokat alkotnak a vállalatok szervezetének és múködésének elemeiben. Jelentôs és nem erôforrás-igényes lehetôség egy vállalat versenyképességének fokozására, ha szervezeti egységeinek vezetôi eleget tesznek az egységre jellemző időfogalom-súlypontok követelményeinek. Ennek érzékeltetésére áttekintjük a következókben a fontosabb szervezeti egységek időfogalom-súlypontjait, s ehhez példaként egy termelővállalat szervezetét választjuk.

- A stratégiai tervezés szervezetében alapvető az irányváltó és az ütemküszöböt átlépó idő érzékelése, méghozzá a hosszú és a középtáv intervallumában egyaránt. Ettôl függ ugyanis a vállalat küldetésének, magkompetenciájának, alapértékeinek és önazonosságának jó megfogalmazása ${ }^{20}$ - vagyis legátfogóbb üzleti céljainak helyes kitúzése. A két időfogalom elsôsorban a vállalat környezetében érzékeli a „külső idő” változásának jellegét. A stratégiai tervezésben azonban számításba kell venni a vállalat múködésének „,belső idejét” is, és ezek közül is fốként a szervezeti és a motivációs időt. Ennek során azt vizsgálhatja a menedzsment, hogy szinkronban van-e a szervezetben érvényesüló idókoncepció és múködési ütem a környezeti idő ütemével, s hogy ezt a szinkront hatékonyan segíti-e a vállalat érdekeltségi rendszere? A szinkron hiánya ugyanis könnyen járhat a versenyképesség elvesztésével - például akkor, ha a vállalat folyamatosan csak nagy késéssel reagál konkurenseinek akcióira. Végül jelentős súlypont, s fóként a multinacionális vállalatok körében, a kulturális időfogalom: ezek hosszú és középtávú eredményeit ugyanis alapvetően befolyásolja, hogy vezetésük reálisan veszi-e számba azoknak a kultúráknak az időfogalmát, amelyek területére ki kívánják terjeszteni üzleti (fóként termelő és csak másodsorban beszerző és/vagy értékesítő) tevékenységüket. A helyi munkatársak lazább időfogalma ugyanis akár keresztülhúzhatja a vállalat céljainak megvalósulását az adott országban vagy régióban.

- A vállalati szervezés körében is alapvetố a szervezeti idő követelményének szem elótt tartása, valamint a külső és a belsô idố szinkronjának a megteremtése. Fơként a túl sok hierarchiai lépcsôvel felépített szervezet múködésének ideje lehet jóval lassúbb, mint a környezet idóüteme. Ilyenkor olyan új formák beveze- 
tését mérlegelheti a szervezetfejlesztés, mint a vállalat karcsúsítása, folyamatainak újjászervezése, tehát egy „reengineering” végrehajtása, vagy projektszervezetek, munkacsoportok és feladatcsapatok életre hívása egyes jól elhatárolható feladatokra. Ezek az új formák jelentős mértékben gyorsíthatják fel egy szervezet belsố idejének ütemét. S ezek bevezetésével a szervezetfejlesztés az idố elemzésének második súlypontjában észlelt hiányosságokat is kiküszöbölheti: jelentôsen lerövidítheti a vállalat reakcióidejét. A szervezetfejlesztés folyamatos súlyponti feladata végül annak a figyelése, hogy nem kerül-e sor a külsố időben irányváltásra vagy az ütemküszöb átlépésére, s hogy elég rövid-e ezek követésére a vállalat reakcióideje? (Ilyen ütemküszöb-átlépés például a piaci kínálat megváltozása akkor, amikor egy versenytárs POS-gyártással ${ }^{21}$ gyorsítja fel a vevőigények kielégítését.)

- Az operatív irányítás területén (ami bizonyos értelemben kakukktojás felsorolásunkban, hiszen ezt nem egy szervezet, hanem a vállalat vezetése végzi ${ }^{22}$ ) több időfogalom kap súlyponti szerepet. A vállalat versenyképessége szempontjából egyre fontosabb, hogy minden szervezeti egységében és múködési folyamatában egységes legyen a szervezeti idő. A reakcióidốt rövidítheti le az információs, a döntési, valamint az ellenőrzési rendszer átszervezése részben az informatika segítségével, részben a korábbinál hatékonyabb döntési rendszerek bevezetésével. ${ }^{21}$ Különösen felgyorsult környezeti változások közepette fontos a kizárólagos idő és az ehhez vezetô fogyó idő érzékelése: ezek szem elótt tartása segítheti a vezetést, hogy jókor ismerje fel a környezet fenyegetéseit, majd ezeket el is kerülje, méghozzá minimális erôforrás-áldozattal. Az optimális idő számbavétele pedig utat nyithat - fớként a vállalati termelésirányítás és a marketingszervezet közremúködésével - a környezetben és/vagy a vállalat múködésében rejlő új lehetőségek gyors kihasználásához. Végül döntő jelentősége lehet (elsősorban a nagy- és óriásvállalatok körében) a kulturális idő érzékelésének: kitelepítések, vállalati összeolvadások és felvásárlások (M+A-k, vagyis „Merger”-ek és „Acquisition”-ok), valamint stratégiai szövetségek sora fulladt kudarcba, mert menedzsmentjük nem vette figyelembe a kulturális idókülönbséget a felek között. Jó példa erre a Daimler-Chrysler vagy a Hewlett-Packard-Compaq M+A-k kezdeti szakaszainak számos, a partnerek elevenébe vágó problémája. ${ }^{24}$

A kutatás és fejlesztés szervezetében az egyik alapvető időfogalom a külsô és a belsố idő szinkronja olyan prognosztizált intervallumban, amelyben nem csupán megtérülnek a $\mathrm{K}+\mathrm{F}$ ráfordítások, hanem növelik is a vállalat nyereségét. Ezt a prognózis jelenérték- idôkoncepciójának segítségével lehet megalapozni, már csak azért is, mert általában több $\mathrm{K}+\mathrm{F}$ koncepció közül választhat a vállalat vezetése. A jelenérték-számítás azonban nem képzelhető el, ha nem mérlegelik, hogy mekkora az irányváltó idő bekövetkezésének valószínúsége. Egy ilyen váltást (és fớként lassulásból gyorsulásba váltást) nagy valószínúséggel idéz elő egy meróben új anyagfajta, vagy egy új, a korábbinál jóval gazdaságosabb technológia megjelenése. Általános követelmény, hogy a $\mathrm{K}+\mathrm{F}$ szervezeteknek egy-egy termék, technológia vagy szolgáltatás kifejlesztését mindig az optimális idôhöz kell igazítaniuk: ahhoz, amelyben a fejlesztés végeredménye - tehát az új termék vagy az új szolgáltatás - a legkedvezóbb feltételek között jelenhet meg a piacon. Ehhez minden $\mathrm{K}+\mathrm{F}$ szervezetnek a fogyó idót is figyelemmel kell kísérnie, hiszen csak így teljesíthetik feladatukat mindvégig időarányosan - márpedig ez a feltétele a szükséges erőforrások minimalizálásának. Végül a $\mathrm{K}+\mathrm{F}-$ nek számba kell vennie a kizárólagos idôt is, hiszen a kutatás-fejlesztési folyamat alatt megjelenhetnek konkurens termékek, amelyek keresztülhúzhatják a megtérülési és a jövedelmezőségi elképzeléseket, vagy megnyílhatnak olyan új lehetőségek, amelyek kiaknázására módosítani kell a $\mathrm{K}+\mathrm{F}$ koncepcióját.

A termelésirányítás számára - minthogy feladatait elsősorban a marketing és a kutatás-fejlesztés szervezeteitól kapja - a súlypont a szervezeti idő. Hatékony múködésének alapja ugyanis a fegyelmezett időgazdálkodás, az „üresjáratok”, a lazaságok kiküszöbölése. Ezenkívül két másik időfogalom érvényesítésének van még nagy jelentősége: a reakcióidónek, amely alatt a termelés át tud állni egyik feladatáról (például egy termék gyártásáról és/vagy technológia üzemeltetéséról) egy másikra - valamint a motivációs időnek, amellyel azonos szintre emeli a termelési folyamat valamennyi munkatársának korábban akár jelentôsen is eltérő időfogalmát, hogy így érje el az egységes és magas szintú munkaintenzitást.

A logisztikai szervezetnek kell ellátnia a termelésirányítást a múködéséhez szükséges energiával, anyagokkal, alkatrészekkel és részegységekkel. Napjainkban egyre bővül a beszerzés földrajzi lehetósége, egyre inkább globális forráskörból válogathat a logisztika. Ezért jelentős munkatársai számára a kulturális idô, vagyis a más kultúrában élő üzleti partnerek időértékelése. Ennek ismeretében kell ugyanis mérlegelniük, hogy menynyire számíthatnak megrendeléseik pontos teljesítésére. Hasonlóan fontos számukra az optimális idópont ismerete, hiszen ez szabja meg, hogy mikor célszerú például előrehozniuk egy-egy megrendelésüket. (Egy ilyen „stratégiai beszerzéssel” ugyanis nagyobb árelőnyre 
tehetnek szert, mint amekkora lesz majd a túl korán beszerzett áruk készletezésének a költsége.) A logisztikai szervezetben nem csupán nagy a szervezeti idő jelentôsége, hanem folyamatosan változik ennek az üteme is, hiszen munkatársainak tevékenységét nem lehet mechanikusan alkalmazott „,normákhoz” mérni. Egy sikeres beszerzés eredményének nagysága és előkészítésének, valamint realizálásának időigénye között ugyanis nincs szabályszerú összefüggés. Végül a munkatársak tevékenységének hatékonyságát számottevően befolyásolja a reakcióidó: nemcsak abban az értelemben, hogy milyen rugalmasan szolgálják ki a termelésirányítás anyag- és energiaigényét, hanem abban is, hogy turbulens világunkban milyen gyorsan reagálnak a beszerzési források körének és feltételeinek változására.

A marketingszervezet számára alapvetố a kulturális idő számbavétele akkor, ha a vállalat olyan országok piacán is értékesít, amelyekben más a vevők - legyenek ezek akár továbbfelhasználók, akár közvetítők, vagy végső fogyasztók - időkoncepciója. A közvetítók - például a helyi ügynökök - jóval lassúbb időfogalma megakadályozhatja például a kereslet új lehetôségeinek gyors kihasználását vagy változásának gyors követését, ami megnyithatja az utat a saját vállalati ügynökökkel értékesító konkurens előtt, hogy akár ugrásszerúen is növelje piaci részesedését. Nyilvánvaló, hogy a marketingszervezet eredményeit döntôen befolyásolhatja a piaci kereslet és kínálat változása. Ezért roppant nagy számára az irányváltó és az ütemküszöböt átlépó idô jelentôsége. És ugyanilyen fontos az optimális idó érzékelése is, vagyis az az idôpont, amikor a legkedvezóbb feltételekkel vezethet be a piacon egy új terméket, amikor a legkisebb veszteséggel jár egy piacról, piaci szegmensról való kivonulás stb. A reakcióidó helyes érzékelése is meghatározó lehet a marketing számára, hiszen ennek segítségével tud gyorsan igazodni a megváltozott piaci feltételekhez. Ebból következik, hogy a rövid reakcióidő a vállalat egésze számára is elengedhetetlen, hiszen a piaci feltételek módosulása többnyire az operatív vállalatirányítás egész tevékenységében kényszeríti ki a célok újrafogalmazását és az eszközök átcsoportosítását. Végül a logisztikához hasonlóan a marketing is olyan vállalati tevékenység, amely nehezen „normázható”, s igencsak szétágazó, tartalmában sokrétú maga a „marketingmix": ezért nagy a marketing szervezetében is a szervezeti idó jelentősége.

A humáneróforrás-menedzsment (HEM) eredményeit két időtávban is befolyásolja a szervezetében kialakuló időfogalom. Közép- és hosszú távon azt kell érzékelnie, hogy várhatóan milyen irányú trendek milyen ütemben valósulnak meg a vállalat múszaki és gazdasá- gi környezetében, vagyis hogy ezekre milyen szakmai tovább- és átképzésekkel szükséges felkészítenie a cég munkatársait. Ez roppant fontos vezetôi döntés, hiszen aligha lehet egy munkatársnak, aki hosszú és fáradságos munkával csak az imént tett szert új ismeretekre, azt mondani: „Most felejtsd el mindezt, és hozz újabb nagy áldozatot: sajátíts el egy másik, új ismerethalmazt!" Igen fontos tehát a HEM számára, hogy jártas legyen az irányváltó és az ütemküszöböt átlépó időfogalom követelményeiben. Rövid távon pedig az hatékonyságának egyik kritériuma, hogy eleget tesz-e a feladatfüggó idó követelményének: sikerül-e létrehoznia a vállalatnál a különböző munkaköröket betöltốk többé-kevésbé homogén idôtudatát, s ezzel egységes ütemú teljesítményüket a mindennapokban. Ezt segítheti elő, ha sikerül kialakítani a vállalat egészében a közel egységes motivációs idốt - mindenekelốtt vonzó vállalati kultúrával és kölcsönös bizalomra épülő vállalati légkörrel. A multinacionális vállalatok körében nélkülözhetetlen a kulturális idő fogalmának és hatásainak számbavétele is, hiszen ez már ahhoz is alapvető feltétel, hogy egyáltalán számba lehessen venni azt a teljesítményt, amelyet a vállalat vezetése a különbözó kultúrájú munkatársakat foglalkoztató üzletegységeitől várhat el.

Az informatika szervezetének - melynek feladata a vállalat információs rendszerének létrehozása, folyamatos fejlesztése, valamint zavartalan múködésének biztosítása - három időfogalom-súlypontja van. A szervezeti idô követelményeinek kielégítése teszi lehetővé, hogy a rendszer minden részében azonos hatékonysággal múködjék. (Ezt az értelemszerúen munkatársi, azaz humán körben érvényesülő idófogalmat azonban alapvetôen befolyásolják a vállalatnál alkalmazott hardver- és szoftvermegoldások.) A rövid reakcióidó annak biztosítéka, hogy a számítástechnikai rendszer folyamatosan alkalmazkodjék a vállalat változó célkitúzéseihez, és az ezek elérését szolgáló múködés újabb és újabb sajátosságaihoz. Amikor például feldarabolták az AT\&T-t, mert már monopóliumközeli helyzetbe jutott, a menedzsment azt a célt túzte maga elé, hogy a vállalat lépjen ki a globális színtérre, és így szerezze vissza elôkelő helyét a Fortune 500-as listáján; ám ehhez igen rövid idő alatt egész informatikai rendszerét át kellett alakítania. Az optimális idő pedig az informatikai rendszer fejlesztése szempontjából fontos, hiszen a legkedvezốbb időpont nemcsak a hardver- és szoftverfejlódés eredményeinek, hanem a vállalat változó múszaki és gazdasági feladatainak is függvénye.

A vállalati nagyberuházásokat és befektetéseket elốkészítő és irányító szervezet esetében nyilvánvalóan döntố jelentósége van az irányváltó, valamint az ütemküszöböt átlépó idő számbavételének, mert ezek 
határozhatják meg egy nagyberuházás, egy befektetés jövedelmezőségét, valamint megtérülésének időtartamát. Ehhez pedig szükség van a jelenérték-számításra is. Jelentôs szerephez jut az optimális idópont követelményeinek figyelembevétele, és nem csupán a nagyberuházások és befektetések megkezdése szempontjából, hanem a beruházások befejezésében és a befektetett pénzeszközök felszabadításában is. Mindez nyilvánvaló, hiszen egy nagyberuházás sikere függ a verseny- és a háttérkörnyezet kedvezóbb vagy kedvezőtlenebb alakulásától - a befektetések körében pedig akár jelentôs vagyonvesztéssel is járhat egy rossz időtartamú lekötés, vagy egy kedvező idôpontot elmulasztó értékesítés.

Végül a vállalati pénzügy és számvitel területén számos időfogalom követelményeinek érvényesítésére van szükség. A megfelelô szervezeti idô teszi lehetôvé, hogy a pénzügyek és a számvitel szervezetei mint támogató szervezetek - illeszkedjenek a vállalat többi szervezeti egységének munkájában érvényesülő időfogalomhoz. Például ne késleltessék lassúságukkal egy új gyártmány fejlesztését, vagy egy új technológia bevezetését. Az irányváltó és ütemet átlépó idő figyelemmel kísérésének egyik eredménye, hogy a vállalat következetesen és időben hajtja be „kintlevőségeit”, de megörzi ebben a rugalmasságát is, vagyis képes arra, hogy méltányos legyen az adósaival szemben, különösen akkor, ha ezt indokolják a jövő üzleti kapcsolatai. A fogyó idő észlelése azt a kötelezettséget rója a pénzügy és a számvitel szervezeteire, hogy annak mértékéról és ütemérôl folyamatosan informálják a vállalat csúcsvezetését. Megsokszorozhatja ugyanis az idő fogyása az ennek alapján bekövetkezó fenyegetés elhárításának forrásszükségletét, ha késnek a csúcsvezetés intézkedései. A kizárólagos idő számbavételére fốként akkor van szükség, ha egy pénzügyi múvelet végrehajtása csupán egyetlen idôpontban lehetséges. Ilyen lehet például - a már korábban említett vagyonértékesítésen kívül - a kedvezô vagyongyarapítás állampapírok, kötvények vagy részvények vásárlásával, vagy egy olyan nagy horderejú vagyongyarapítás, amely vagy a vállalat profilját egészíti ki vertikális diverzifikálással, vagy a vállalat üzleti biztonságát növeli horizontális diverzifikálással. Végül számottevő követelmény a vállalati pénzügyek és a számvitel szervezeteivel szemben a rövid reakcióidó: múködésükkel szorosan illeszkedniük kell a vállalat többi szervezeti egységének tevékenységében megvalósuló tartalmi és ütembeli váltásokhoz - például olyan új termékek gyártásához, melyek felgyorsítják a termékkibocsátást, vagy olyan új marketingakciókhoz, amelyek jelentősen megnövelik egyes gyártmányok értékesítését a piacon.
Az időfogalom súlypontjainak áttekintése a fontosabb vállalati szervezeti egységekben felhívja a figyelmet arra, hogy hasznos, ha a vállalat csúcsvezetése megismerteti a szervezetek vezetôivel az időfogalom követelményeit, majd be is számoltatja a vezetóket, hogy irányításuk során folyamatosan figyelemmel kísérték-e az ilyen időfogalmak követelményeinek alakulását, és hogy idejében eleget tettek-e a követelményeknek? Hiszen ha ezeknek nem, vagy hiányosan, vagy csak késve tesznek eleget, akkor mulasztásuk nem csupán az általuk vezetett szervezeti egység teljesítményét, hanem a vállalat egészének versenyképességét is veszélyezteti.

\section{„Hármas tükörmodell” az idố gyorsulásának és lassulásának elórejelzésére}

Gondolatmenetünk bevezetôjében felsoroltuk azt a négy tényező́csoportot, amelyet célszerú vizsgálni egy sikerre törekvő üzleti stratégia megtervezésekor. Most tekintsük át, hogy fóként kikre, illetve mire terjedjen ki a négy tényezốcsoport mindegyikének elemzése!

(a) A müszaki fejlôdés tényező́csoportjába a következók tartoznak: 1. A múszaki fejlódés irányán, mértékén és ütemén belül azok a trendek és elért eredmények, amelyek az adott iparág termékeinek, ezek anyagának, gyártásuk technológiájának területébe sorolhatók, valamint az adott iparág szolgáltatásainak a fejlődése. 2. Az iparág termékeit vagy szolgáltatásait felhasználóinak körében bekövetkezett múszaki fejlesztések iránya, mértéke és üteme. 3. Végül más iparágakban végbement olyan múszaki fejlődések iránya, mértéke és üteme, amelyeknél számítani lehet a fejlesztések diffúziójára - tehát elterjedésére az eredetileg vizsgált iparágban, illetve átáramlására az annak termékeit vagy szolgáltatásait felhasználók körébe. A múszaki fejlôdés korunkban globális szinten folyik, de lokális szinten jelenik meg. Ezért a fejlődést mindig globális és lokális szinten kell vizsgálni és értékelni, s egy helyes prognózis alapvető követelménye a két szint között kialakuló rés, a „gap” azonosítása. Ezért a múszaki követési távolság megbízható előrejelzésének technikája a távolságelemzés, a ,gap analysis”. ${ }^{25}$

(b) A második tényező́csoport a versenypiacé. Ennek területén négy jellegzetes szereplő helyzetét és tevékenységét célszerú felmérni: 1 . A versenytársak helyzetét, piaci stratégiáját és piaci akcióit (fóként piacszerkezetük, piaci részesedésük, termékeik, szolgáltatásaik, árpolitikájuk és marketingakcióik vonatkozásában), valamint az ezek hatását a kereslet és a kínálat alakulására. 2. A vevók keresletének változását, nevezetesen a tartalmi, intenzitás- és ütembeli változást, valamint a kereslet módosulásának okait (például a piac telítődé- 
sét, a vásárlás késleltetését stb.). 3. Az üzleti partnerek kínálatában bekövetkezô változásokat (kiválásukat az üzleti életból, új partnerek jelentkezését kedvezốbb ajánlatokkal stb.), valamint megváltozó szerepüket egy már kialakított termelési-szolgáltatási hálózatban (például lemaradásukat a múszaki fejlesztésben az integrátor vállalattal szemben). 4. Végül egy adott ország vagy régió kormányzatának már meghozott, valamint még csak tervezett intézkedéseit, amelyek a piacszabályozás eszközeivel befolyásolják (szigorítják, könnyítik, meghatározott irányban ösztönzik stb.) a többi piaci szereplő terveit és tevékenységét. A versenypiac mindig lokális, de beágyazódik egy globális piacszerkezet hatásainak, hatásláncainak, hatáshálóinak és hatásmezóinek szövevényébe. Ezért egy-egy piac eseményeinek prognózisa akkor megbízható, ha eseményeinek, folyamatainak elôrejelzésekor figyelembe veszik, méghozzá globális szinten, részben a piaccal közvetlen kapcsolatban álló, részben a fó jellemzóivel azonos külső piacok eseményeit és folyamatait is: ennek a kettós piacelemzésnek a technikája a ,dual market analysis”. ${ }^{25}$

(c) A múszaki fejlődés és a versenypiac folyamatait befolyásolják, sőt akár alapvetően is meghatározhatják a gazdasági-társadalmi háttértényezók. (Például egy tartós recesszió, az ország pénzügyi rendszerének öszszeomlása, erôszakos cselekményekbe torkolló társadalmi feszültségek stb.). Az idő gyorsulásáról vagy lassulásáról szóló prognózis egyik legnehezebb feladata annak számbavétele, hogy az ütem változásában mely háttértényezók játszanak majd szerepet; hogy ezek milyen irányban, milyen mértékben és milyen tartósan fejtik majd ki a hatásukat; s hogy előrejelzésük bekövetkezésének mekkora a valószínúsége. A megbízható előrejelzést két elemzés segítheti: 1 . annak vizsgálata, hogy mekkora feszültség jön létre egy-egy háttértényezóben, illetve mekkora feszültséget kelt egy adott tényező alakulása a gazdasági-társadalmi háttértényezők szövevényében, valamint 2 . annak feltárása, hogy egyegy tényezố alakulása mekkora fejlódést (változást) indít meg akár a háttértényezók szövevényén belül, akár a múszaki fejlődésben és/vagy a versenykörnyezetben. Ezt a két elemzést mind globális, mind lokális szinten célszerú elvégezni - és ezekben kaphatnak nagy szerepet a hatásokon kívül a hatásláncok, a hatáshálók, sốt a gazdaságok egészét befolyásoló hatásmezők is. Az ilyen vizsgálatok technikája a feszültségintenzitás, valamint a fejlódésindukálás elemzés, vagyis a „tensionanalysis” és az ,innovation-diffusion analysis”.

A felsorolt három tényezócsoport mindegyikének eseményei és folyamatai - ahogy már említettük - lokális és globális szinten jelennek meg és hatnak az eseményeikkel és folyamataikkal szembesülő vállalatra.
S a szintek között egyre szervesebbek a kapcsolatok. Vagyis három jól elkülöníthetó, de egymással összefüggó szintet jelenítenek meg az elemző menedzser számára, s ezek történéseit, valamint az események bekövetkezésének idejét mind kevésbé lehet elszakítani egymástól. Ennek a három szinten folyó elemzésnek a tartalmi öszszehangolását segítheti a nemzetgazdasági és a vállalati versenyképesség tükörmodellje, majd a nemzetgazdasági modell kiterjesztése globális tükörmodellé.

Témánk, vagyis az idő aspektusai szempontjából azért van kitüntetett szerepe a hármas tükörmodellnek, mert korunk felgyorsult időuitemében a vállalatok vezetôinek már nem elég csupán a hosszabb távú elôrejelzéseket (például piac- és gazdaságkutató intézetek, pénzintézetek, kormányzatok stb. éves vagy még hosszabb időszakra szóló prognózisait) figyelembe vennie. A menedzsereknek, a vállalatok stratégiai és operatív tervezó szervezeteinek szükségük van olyan „gyorstesztre” is, amellyel mintegy menet közben ellenórizhetik az ilyen hosszabb távra szóló előrejelzések érvényességét. És egy ilyen ,gyorstesztben” nem szerepelhet a hosszú távú tervezéssel hivatásszerúen foglalkozó intézmények modelljeinek roppant sok, a vállalati tervezés számára már áttekinthetetlen számú tényezójje ${ }^{26}$ : ezek közül csak a súlypontiak épülhetnek be a modellbe. Ám ezek tegyék lehetôvé azt is, hogy a változásokat az adott vállalatnak és versenykörnyezetének a szempontjából is értelmezni lehessen. Ezt segíti tehát a hármas tükörmodell.

A hármas tükörmodell mindhárom részének - melyek tehát a vállalati, a nemzetgazdasági és a globális szintnek felelnek meg - azonos a struktúrája. Ezt a 4. ábra mutatja be, amelyben a modell tényezóit - a modellrészek négy kérdéskörének megfelelően - A, B, C és $\mathrm{D}$ betúk jelölik.

A hármas tükörmodell részeinek struktúrája: a négy ( $A, B, C$ és $D$ kérdéskör)

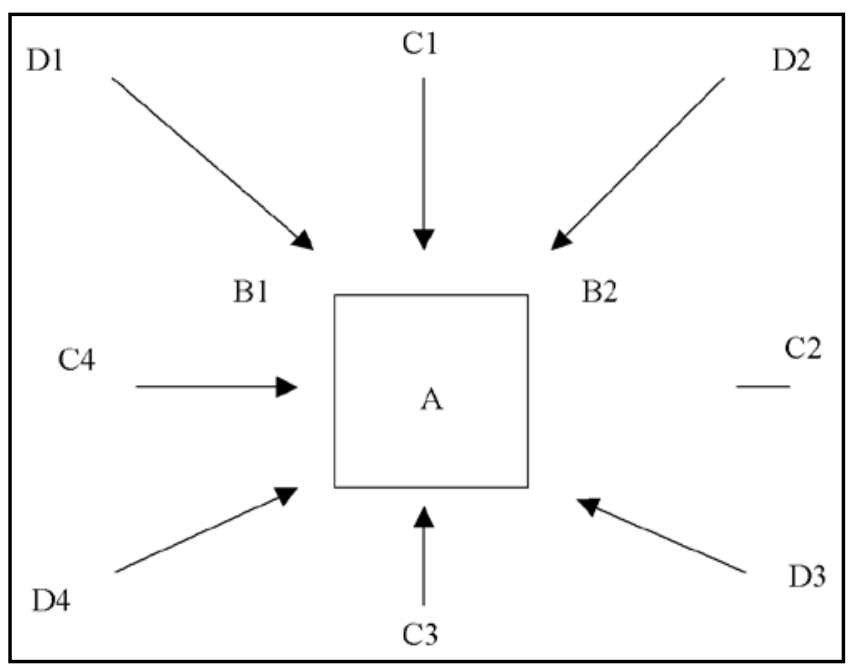


Az egyes tükörmodellrészek tartalma, tehát az A, B, C és D betújelek fogalmai a következók:

A vállalati modell elsô és második kérdésköre négyzettel ábrázolható. (A makrogazdasági modell bemutatásakor kitûnik majd, hogy ezzel emlékeztet a nemzetgazdaság ún. „,bưvös négyzetére”.) A négyzet középpontjában az első kérdés a vállalat versenyképessége, és ennek kapcsolata az idô ütemével, négy sarokpontjában pedig, második kérdéskörként, az üzleti stratégia négy „dimenziója”, a múszaki/tudományos fejlődés, a vállalati versenykörnyezet, a gazdasági/társadalmi háttérkörnyezet és az idő dimenziója szerepel.

- A müszaki/tudományos fejlódéshez való csatlakozás két formában is történhet: képviselheti a fejlődés élvonalát (fóként globális innovációkkal), vagy követheti ezt olyan távolságból, amelyik még nem fenyeget leszakadással. A siker alapvető feltétele mindkét forma esetében az, hogy a fejlettség szintje pontosan megfeleljen az értékesítéshez kiszemelt piac fizetőképes keresletének. ${ }^{27}$

- A versenykörnyezet dimenziójában a siker feltétele napjainkban már nem csupán a jól megválasztott magkompetencia, hanem az is, hogy a vállalat - a múszaki/tudományos fejlődéshez és a gazdasági háttérkörnyezet változásához igazodva - folyamatosan megújítsa magkompetenciáját. ${ }^{28}$

- A gazdasági/társadalmi háttérkörnyezet fóként annak számbavételét követeli meg, hogy a gazdaságok és társadalmak fejlettségi szintje és ennek változása milyen irányba és milyen ütemben „,tereli” az üzleti stratégia célkitúzéseit, és hogy ezek megvalósítására mekkora kockázattal, mekkora erőforrásokat célszerú fordítani. Ennek a ,terelésnek” a mértéke iránymutató ahhoz is, hogy egy vállalat menedzsmentjének milyen érzékenyen (mekkora ráfordítással, milyen technikával stb.) kell figyelemmel kísérnie a háttérkörnyezet változásait.

- Az idő „dimenziója” azért alapvető, mert gyorsulásának vagy lassulásának nem csupán a vállalat operatív múködésében, hanem jövőjének alakulásában, elsősorban fejlesztéseiben van meghatározó szerepe. A gazdaság lassulásának időszakában végzett gyártmány- vagy gyártásfejlesztések - miként erról már szó volt - akár sorsdöntő előnyt is adhatnak a konkurensekkel szemben, hiszen segítségükkel a vállalat már a gazdasági növekedés felgyorsulásának kezdetén meróben új, versenyképesebb kínálattal jelenhet meg a piacon.

A modell harmadik kérdésköre Michael E. Porter jól ismert vállalati versenymodelljének négy tényezőjét foglalja magában. A globális háttér szempontjából főként a következő sajátosságok jellemzik ezt a négy tényezőt:
- A piacra újonnan belépók száma szinte beláthatatlanul megsokszorozódhat, ami a korábban kialakult piaci egyensúlyokat alapvetően veszélyeztetheti, s ezzel szinte folyamatosan megkérdőjelezi valamenynyi piaci szereplő biztonságát.

- A szállítók alkupozíciója nagyságrendekkel gyengülhet: körük könnyen kitágul akár a világgazdaság egészére; a korszerü információtovábbítás technikája pillanatok alatt teszi lehetővé az új szállítókkal való kapcsolatfelvételt, majd az üzleti kapcsolatok tető alá hozását; végül még az igen távoli szállítóktól való beszerzéseket is gazdaságossá tehetik a korszerú szállítási megoldások (a konténerek és szállítóhajóik, a jumbókat használó légi teherszállítás stb.).

- A vevók alkupozíciója erősödik, éppen a szállítók esetében felsorolt tényezók ellenkező irányú hatására. Az erósödést mérsékelheti viszont az a törekvésük, hogy beszerzéseik tegyék lehetôvé - fooként a felgyorsuló fejlődés következtében lerövidülő megtérülési lehetôség miatt - egyedi versenyelőny kialakítását. Márpedig ez nemritkán olyan sajátos igény megfogalmazására készteti a vevôket, amelynek kielégítése erôsíti a szállító alkupozícióját.

- A helyettesító termékek körében azt a sajátosságot érdemes kiemelni, hogy a mind globálisabbá szélesedő kínálat kitágítja a helyettesítő termékek körét; a vevôk többségének növekvő vásárlóereje pedig kedvez annak, hogy egyre többen kísérletezzenek különbözô helyettesítő termékek vásárlásával és fogyasztásával.

A modell negyedik, és utolsó kérdéskörében ismét négy tényezô befolyásolja a vállalat eredményét. Ezek a következók: a vállalat alapértékei (a „Core values”), az üzletvitel, általában az éves múködés számszerú eredményei, a vállalat erôforrásai, valamint a szervezet, a múködési folyamatok és rendszerek sajátosságai. Ezek néhány újabb jellemzője a következő:

- A vállalat alapértékei között kimagaslóan nagy lett a kreativitás, a ,Life-Long-Learning” (a 3L, a munkában töltött élettartam egészét átfogó folyamatos tanulás) és a tudásátadás, valamint a magkompetencia jelentősége - beleértve az utóbbi érvényesülését segítő múködési formát, egy vállalat termelési-szolgáltatási hálózatban, klaszterban való múködését.

- Az (éves) üzletvitel eredményeiben egyre meghatározóbb, hogy mekkora a vállalat vezetésének nemzetközi versenyképessége mind a vezetési koncepciók, mind a vezetési technikák és a vezetési stílusok tekintetében, s hogy ez a három mennyire segíti kibontakozni részben a munkatársak innovációs készségét, részben a vállalat múködésének rugalmasságát. ${ }^{29}$ 
- A vállalat eróforrásainak körében kiemelkedik a humán erőforrásnak és menedzselésének jelentôsége. A humán erőforrások egyre idôigényesebb és egyre kockázatosabb fejlesztésének már nem csupán a napi múköódésben, hanem a stratégia idôtávjában, tehát a hosszú távú fejlesztésük irányában és mértékében is szinkronban kell lenniük a vállalat technikai és pénzügyi erőforrásaival.

- Végül a szervezet, a folyamatok és a rendszerek körében egyre nagyobb a multidiszciplináris szervezetek (a divíziók, a munkacsoportok és feladatcsapatok, valamint a projektszervezetek) jelentôsége. A folyamatokban mindazok számára parancsoló követelmény a hozzáadott szellemi érték magas aránya, akik nem akarnak tartós és egyre nagyobb bérszínvonal-áldozatot hozni versenyképességük fenntartására. A rendszerek két alapvetô célja pedig a múködés felgyorsítása és a hagyományos vállalati funkcióhatárok (tehát a $\mathrm{K}+\mathrm{F}$, a termelés/szolgáltatás, a marketing, a vállalati pénzügyek stb. határainak) áttörése, „légiesítése" - fóként új típusú információs rendszerek ${ }^{30}$ segítségével.

A tükörmodell nemzetgazdasági részében is négy kérdéskörben helyezkedik el a négy-négy tényező. Ezek kérdéskörönként és egy adott idôpontra vagy időszakra vonatkoztatva a következók:

- Az elsó két kérdéskör - mint már említettük - a klasszikus „búvös négyzetet” foglalja magában. A négyzet középpontjában, elsô kérdésként - a mikromodellben látható ,versenyképesség” analógiájára - a kormányzat gazdaságpolitikája és gazdaságszabályozó intézkedései szerepelnek mint a gazdaság egészének versenyképességét serkentő vagy fékező tényezốk, valamint ezek hatása az idő nemzetgazdasági szinten érzékelhetô ütemére. A második kérdéskör a négyzet négy sarokpontja, amelyek a gazdaság növekedésének (a GDP-nek, a társadalmi összterméknek) az alakulását, a foglalkoztatás szintjét és szerkezetét, az inflációs rátát, valamint a gazdaság ugyancsak számos vonatkozású (államháztartási, költségvetési, külkereskedelmi, folyó fizetési mérlegbeli, fogyasztási-beruházási, szociális ellátórendszer-kiadási és -finanszírozási stb.) egyensúlyi helyzetét jelzik.

- A modell harmadik kérdéskörének négy tényezóje a termelékenység, valamint a hatékonyság alakulása a nemzetgazdaságban (az előzóbe beleértve a munkaés a teljes termelékenység mérôszámát, a nemzetközi szintú hatékonyság mérésére pedig elsősorban a cserearány-mutatók, a „terms of trade”-ek alkalmasak); a gazdaságban megnyilvánuló innovációs kész- ség mértéke (ezt érzékeltetheti többek között egy adott időszakban elfogadott szabadalmi bejelentések száma is); végül annak feltárása, hogy mekkora a nemzetközi szintû termelési/szolgáltatási hálózatok keretében létrejött output aránya a teljes nemzetgazdasági outputhoz képest.

- A negyedik kérdéskör tényezói azt jelenítik meg a modellben, hogy miként igazodik a nemzetgazdaság súlyponti ,iparágainak” 31 múszaki fejlettsége a világ élvonalához (azt reprezentálja-e, vagy azt, hogy mekkora távolságban követi az élvonalat); hogy mekkora előrelépés vagy visszaesés után hol helyezkedik el a nemzetgazdaság az országok globális gazdasági rangsorában; s hogy mennyire épült be a gazdaság a nemzetközi munkamegosztásba; s végül miként alakult és mekkora volt mind a múködó-, mind a portfóliótóke beáramlása a gazdaságba.

A vállalatok és nemzetgazdaságok versenyképességének alakulását, az idő gyorsulásának és lassulásának, valamint a különböző időtípusoknak a hatását a versenyképességre egyre erôteljesebben befolyásolják a globális események és folyamatok. Ezért szükséges a tükörmodell nemzetgazdasági részét a globális összefüggések rendszerében is értelmezni. Az ezt szolgáló globális modell szerkezete azonos a nemzetgazdasági modellével, de tényezói jórészt új értelmet kapnak a következők szerint:

- A modell középpontjában elsó kérdésként egyelőre hívságos lenne a világgazdaság múködésének befolyásolására törekvő nemzetközi szervezetek, a World Bank, az IMF, a WTO stb. gazdaságpolitikáját és gazdaságszervezô intézkedéseit beilleszteni. Ezek helyett célravezetốbb, ha itt a világgazdaság összes hozamának és összes ráfordításának arányszámát, és ezek idôszakos változását szerepeltetjük, valamint a globális múszaki, gazdasági és társadalmi folyamatok ütemére kifejtett hatásukat tüntetjük fel. A modell második kérdéskörében a gazdasági növekedésben és a foglalkoztatásban célszerú számításba venni - miként erról már volt szó - a világgazdaság alakulását meghatározó országokat és országcsoportokat, tehát a „mozdonyországokat” (a továbbiakban MOkat) és az ,aknamezős országokat” (a „továbbiakban AO-kat). Az inflációs ráta számbavétele fóként a kulcsvalutájú országok esetében fontos mutató, ám ezek körében célszerú figyelembe venni ezek államháztartási, folyófizetésimérleg- és külkereskedelmi adatait is, amelyek feltárhatják egy várható infláció veszélyét is. Az egyensúly kérdéseit szintén az MOés AO-országok és országcsoportok körében indokolt elemezni. 
- A harmadik kérdéskör tényezói a termelékenység, a hatékonyság és a vállalatok körében kialakult nemzetközi termelési és/vagy szolgáltatási hálózatok (klaszterek) számának alakulása - ez a három tényezô az MO-k és az AO-k körében -, valamint a létrejött globális innovációk számának változása.

- Végül a globális modell negyedik kérdéskörének tényezôi a múszaki fejlódés és a gazdasági növekedés ütemének változása, a nemzetközi munkamegosztás mértéke (a külkereskedelem és a külgazdasági kapcsolatok volumenének változása), valamint a múködó és a portfóliótóke nemzetközi áramlása, méghozzá a világgazdaság egészében.

A hármas tükörmodell részeiben szereplő kérdéskörök, illetve tényezőik áttekintését és mintegy a 4. ábra értelmezését könnyíti meg az 1. táblázat.

Mindezek után felvetődik végül a kérdés: miként használható a tükörmodell és globális kiegészítése az idő gyorsulásának és lassulásának, valamint a többi időaspektus változásának az elôrejelzésére? Ehhez a következő négy lépésból álló elemzés ajánlható:

1. A modell valamennyi tényezôjénél ki kell jelölni azt az értéksávot („tưréssávot”), amelyen belül a tényezô nem váltja ki az idő gyorsulását, lassulását vagy más jellemzőjének kritikus megváltozását. Kritikus minden olyan változás, amelyik hatásával, hatásláncával, határhálójával vagy hatásmezójével eléri a vállalatot, és számára a versenyképesség új lehetôségét nyitja meg vagy azt új fenyegetéssel veszélyezteti. A sáv szélességének meghatározására alkalmas lehet egy plusz-mínusz értékú százalékos skála (például a foglalkoztatás vagy az infláció változásának érzékelésére), vagy egy plusz-mínusz pontrendszer (például egy Likert-skála az innovációk jelentôségének érzékeltetésére). Ilyen értéksávok kijelöléséhez jó támpontot adhatnak az elmúlt idôszak gazdaságelemzési és -előrejelzési adatai.

2. Végig kell követni - méghozzá a globális modellen kezdve, s onnan „visszafelé”, tehát elóbb a nemzet-

A részmodellek betújeleinek tartalma

\begin{tabular}{|c|c|c|c|}
\hline \multirow{2}{*}{$\begin{array}{c}\text { A részmodellek } \\
\text { kérdésköreinek } \\
\text { tényezóit jelzó } \\
\text { betúk }\end{array}$} & \multicolumn{3}{|c|}{ A betújelek tartalma } \\
\hline & a vállalati részmodellben & a nemzetgazdasági részmodellben & a globális részmodellben \\
\hline A & A vállalat versenyképessége & $\begin{array}{l}\text { A kormányzat gazdaságpolitikája, } \\
\text {-szabályozása }\end{array}$ & $\begin{array}{l}\text { A világgazdaság összes hozama } \\
\text { és ráfordítása }\end{array}$ \\
\hline B1 & $\begin{array}{l}\text { Múszaki-tudományos fejlôdés } \\
\left(\text { WARD }^{2}\right)\end{array}$ & A gazdaság növekedése (GDP) & $\begin{array}{l}\text { A gazdasági növekedés mértéke } \\
\text { globálisan** }\end{array}$ \\
\hline B2 & Versenykörnyezet (SWOT) & A foglalkoztatás mértéke & $\begin{array}{l}\text { A foglalkoztatás alakulása } \\
\text { globálisan** }\end{array}$ \\
\hline B3 & Háttérkörnyezet (STEEPLE) & Az inflációs ráta alakulása & Az infláció alakulása globálisan** \\
\hline B4 & Idő (3MAST) & A nemzetgazdaság egyensúlya* & Az egyensúly alakulása globálisan** \\
\hline $\mathrm{C} 1$ & A piacra újonnan belépók & A termelékenység alakulása & A termelékenység alakulása** \\
\hline $\mathrm{C} 2$ & A szállítók alkupozíciója & A hatékonyság változása & A hatékonyság változása** \\
\hline $\mathrm{C} 3$ & A vevôk alkupozíciója & Az innovációs készség mértéke & A létrejött globális innovációk száma \\
\hline $\mathrm{C} 4$ & Helyettesítő termékek & $\begin{array}{l}\text { Nemzetközi hálózatban létrejött } \\
\text { output aránya }\end{array}$ & $\begin{array}{l}\text { Az újonnan alakult nemzetközi } \\
\text { termelési hálózatok száma }\end{array}$ \\
\hline D1 & A vállalat alapértékei & $\begin{array}{l}\text { Súlyponti iparágak fejlettségi szintje } \\
\text { globális élvonalhoz mérve }\end{array}$ & $\begin{array}{l}\text { A múszaki fejlődés ütemének } \\
\text { változása }\end{array}$ \\
\hline D2 & Az (éves) üzletvitel eredményei & $\begin{array}{l}\text { A gazdaság helye a globális } \\
\text { rangsorban }\end{array}$ & $\begin{array}{l}\text { A gazdasági növekedés ütemének } \\
\text { változása }\end{array}$ \\
\hline D3 & A vállalat erőforrásai & $\begin{array}{l}\text { Részvétel a nemzetközi } \\
\text { munkamegosztásban }\end{array}$ & $\begin{array}{l}\text { A nemzetközi munkamegosztás } \\
\text { globális változása }\end{array}$ \\
\hline D4 & $\begin{array}{l}\text { A vállalat szervezetei, folyamai, } \\
\text { rendszerei }\end{array}$ & $\begin{array}{l}\text { A múkködő és a portfóliótóke } \\
\text { beáramlásának mértéke }\end{array}$ & $\begin{array}{l}\text { A múködő és a portfóliótóke globális } \\
\text { áramlásának változása }\end{array}$ \\
\hline
\end{tabular}

* Az egyensúly néhány fontosabb tényezőjét tartalmazza a szöveges rész.

** Ezeket a tényezóket az ún. „mozdony-” és „,aknamezôs” országokban célszerú elvégezni. 
gazdasági, majd a vállalati modell irányában -, hogy a modellek egyes tényezóibool milyen hatások, hatásláncok, hatáshálók és hatásmezók indulnak ki, s hogy ezek milyen újabb tényezôk alakulását befolyásolják. Ennek során háromféle hatás jöhet létre: erôsítő, gyengítő vagy közömbösítő hatás. Ezek tehát vagy még jobban kitérítik egy-egy tényezô értékét tưréssávjából, vagy közelítik ahhoz, vagy a közömbösítő hatásukkal visszavezetik a túréssávba.

3. Ezután kerülhet sor a modell tényezőinek súlyozására. A globálissá bôvített tükörmodellnek lesznek ugyanis olyan tényezôi, amelyek meghatározó szerepet töltenek be az idő egy-egy aspektusának megváltozásában, például gyorsulásában vagy lassulásában (erre lehet példa egy nagy és tartós egyensúlyhiány az MO-k egyikében. Lesznek olyan tényezői, amelyek hatása átlagosnak tekinthető (például a múködőtóke-beáramlás tartós, de kismértékú csökkenése egy nemzetgazdaságban). S lesznek olyanok, amelyek hatása csak kevéssé érzékelhető (például egy vállalat fizetóképességének átmeneti csökkenése mint a vállalat múködési idejét csak rövid távon gyorsító tényezố).

4. A lépések eredményeként kialakuló összkép pedig nemcsak érzékeltetheti az idő több jellemzójének változását, hanem jó szakmai érveket is ad mind a változás elórejelzéséhez, mind a prognózis hitelének az alátámasztásához. Kétséges azonban, hogy a „,megoldást" bármikor is matematikai modellbe lehet majd foglalni. Ezt ugyanis megnehezíti a tényezók nagy száma, tartalmuk sokszor eltérő mértékegysége, valamint a köztük létrejövô hatások bonyolult összefüggése.

Ennek a bonyolult, soktényezôs és sok variációval számoló elemzésnek minden részfeladata azonban aligha lehet csupán egyetlen vállalat stratégiai tervező szervezetének a feladata - legyen az akár egy multinacionális óriásvállalat. Néhány részfeladatot ugyanis csak az annak problémáira szakosodott tervező szervezet képes hatékonyan elvégezni. Jelentôsen megdrágíthatja viszont az elemzést - különösen kisebb vállalatok számára -, ha ebbe külső szakmai szervezeteket is be kell vonni. A prognózisnak ezzel a tetemes költségnövelő hatásával azonban még a kisebb vállalatoknak sem kell számolniuk. Az előrejelzésre szakosodott szervezetek információit ugyanis számos kis- és középvállalat használhatja fel, s ezért közösen állhatják az előrejelzés költségeit. Ennek ismeretében kamaráik vagy más szakmai szervezeteik vállalhatják, hogy megszervezik körükben a kutatás közös finanszírozását. Az általános múszaki-gazdasági kilátások így elkészített prognózisa után pedig már csak a prezentált tényezőalakulások és szcenáriók vállalati hatásának mérlegelése és értékelése a kis- és középvállalatok vezetőinek a feladata.

\section{Lábjegyzet}

${ }^{1}$ Hawking, S. H.: Az idő rövid története. Bp, 2001. Talentum Kft.

2 A ,reprezentáló szereplók" összetételére még visszatérünk a következőkben.

${ }^{3}$ Az elemzés lényege annak feltárása, hogy milyen külsô (elsôsorban piaci) és belső (vállalati) feltételek hatására lesz jövedelmező egy vállalat számára a három jellegzetes fejlesztési pozíció közül az egyik vagy a másik.

${ }^{4}$ ASWOT betúszó feloldása: Strong and Weak points, Opportunities and Threats. A három idóbeli metszetet pedig a (p,f,r) index jelöli, melynek feloldása: present, future, reaction.

${ }^{5}$ STEEPLE betúszó angol fogalmai: Social, Technical, Economic, Environmental, Political, Educational. A három földrajzi metszetet a (h,o,g) index jelöli, melynek feloldása: home, overseas, global.

${ }^{6}$ Ha nem korlátozzuk a ,vállalat” fogalmat, ez minden vállalatot és vállalkozást magában foglal, legyen bármekkora azok nagysága, bármilyen a profilja, tulajdonformája stb.

Ami nem jelenti azt, hogy ennek az időtípusnak a feltételei között nem születhetnének akár végzetesen rossz döntések is akár makro-, akár mikrogazdasági szinten.

${ }^{8}$ Ez volt annak idején a Tungsram Rt. dilemmája az elektroncsövek világpiacán.

9 Ezzel kapcsolatban érdemes felhívni a figyelmet arra, hogy korunkban már nem csupán a gazdálkodó szervezetek, hanem a vállalatok vezetoói, sốt a kormányok is résztvevơi a közöttük folyó világméretú versenynek.

${ }^{10}$ A vállalati körben elsősorban a multinacionális korporációk múködése gyorsította fel az időt.

${ }^{11}$ A nagyvállalati múködés gyakorlatában természetesen soha nem lehet kizárólag a magkompetenciára szúkíteni a profilt: ezt a múködés biztonságának a szempontja sem engedi meg.

${ }^{12}$ Ezért fogalmazott úgy Bill Gates egyik interjújában, hogy a stratégiai szövetségek elôbb-utóbb meg fogják változtatni a piaci verseny természetét.

${ }^{13}$ Egy multidiszciplináris (több szakmájú munkatársakkal múködő) szervezetben helyet kap például a kutatómérnök, a termelésszervezố, a marketing és a pénzügyek szakembere, a vállalati humánpolitikus stb.

${ }^{14}$ Ez a válságmenedzselés egyik klasszikus módszere: válságmenedzsere például így változtatta két év alatt „,profitgyárrá” a már súlyosan veszteséges Memorexet.

${ }^{15}$ A fejlesztési idő ilyen lerövidítése cáfolja azt a régebbi állítást, hogy ,az eltékozolt idốt” nem lehet behozni.

${ }^{16}$ Fogalmaink szerint a bolygóvállalat egyetlen integrátornak szállít, a beszállító vállalat pedig több megrendelő vállalattal is üzleti kapcsolatban van.

${ }^{17}$ Ez igaz addig a határértékig, amelyet elérve már csak egyetlen lehetôség marad a vállalat, illetve menedzsmentje számára.

${ }^{18}$ Ilyen kockázatot vállalt évekkel ezelőtt - sikerrel - az Intel vezetése.

${ }^{19}$ Ez alól kivétel azoknak a vállalatoknak a tevékenysége, amelyek - a piaci igényekkel összhangban - jövedelmezóen tudják megvalósítani a „Start with Global Selling!” elvét.

${ }^{20}$ Ezeket jelöli a már ,,nemzetközinek” számító angol nyelvú szakirodalom a „mission”, ,core competencies”, ,core values” és „corporate identity” kifejezésekkel.

${ }^{21}$ POS = Point of Sale, azaz az értékesítés pontján megvalósuló gyártás. Így gyorsították fel például a japán gyártók a nyomott textíliák értékesítését azzal, hogy a nyomóberendezést tengerjáró 
hajóra szerelték, s erról szolgálták ki közvetlenül a kiskereskedőket számos nagy nyugati kikötôvárosban.

${ }^{22}$ Az óriásvállalatok körében egyre gyakrabban választják külön a stratégiával foglalkozó csúcsvezetési feladatkört (ezt a Chief Executive Officer, a CEO tölti be), valamint az operatív irányítást (ami a Chief Operation Officer, a COO tennivalója).

${ }^{23}$ Ilyen döntési technika például az „Ötlépéses vezetối döntés” („Management's Five Step Decision Making System”). Ennek fázisai a következốk: 1 . A vállalat vezetôje kijelöli a döntési folyamatban résztvevóket. 2. Írásban közreadja a döntési feladatot, megoldásának szempontjait és az ajánlott megoldást. 3. A folyamatban részt vevớk értekezleten, korlátozott időtartamú hozzászólásokban ismertetik álláspontjukat: egyetértésüket, ellenvéleményüket vagy új javaslataikat. 4. A vállalat vezetôje tételesen értékeli a felvetéseket. 5. A vállalat vezetôje meghozza döntését, és ezt részletesen indokolja a korábban más véleményt hangoztatók meggyőzésére, majd a döntés végrehajtásáért felelősöket.

${ }^{24}$ Mint közismert, ez a Hewlett-Packard - Compaq vállalatok esetében a csúcsvezetô leváltását vonta maga után.

${ }^{25}$ A követési távolság elemzése az élvonalbeli vállalatok vezetói számára is fontos feladat: ennek segítségével érzékelhetik ugyanis versenyelőnyük nagyságát.

${ }^{26}$ A svájci IMD például 288 tényezôs modellt használ éves és hoszszú távú prognózisához.

${ }^{27}$ Sok olyan múszaki eredményrôl tudunk, amely csak több évvel, vagy akár évtizeddel a létrehozását követóen vált sikeressé a piacon. Márpedig - Josef Alois Schumpeter meghatározása szerint - még egy múszaki innováció is csak a piacon, a piaci elismerésben jön létre.

${ }^{28}$ Ezért is van szükség a nagyvállalatok felsővezetésében a CCCO, a „Chief Core Competence Officer” tevékenységére.

${ }^{29}$ A vállalatvezetők szerepének ezt a növekedését jelzik - sokszor már aránytalanul is - a munkatársai fizetésétől mind jobban elszakadó csúcsvezetói mamutjövedelmek.

${ }^{30}$ Így jelentek meg a korábbi egy- és kétirányú információs rendszerekkel szemben az „átlós”, a „sugaras” és a „körkörös” rendszerek.

${ }^{31}$ Az ,,iparág” fogalom itt az angol „,industrynak” felel meg, amelyik szolgáltatásokat is magában

\section{Felhasznált irodalom}

Acbert, B.Z. (2000): Time and Chance. Cambridge, Mass. Harvard University Press

Brunn. S.D. - Leinbach, T.R. (1990): Collapsing Space and Time. London, Harper Collins

Carr, D. - Chain-Fai, Ch. (2004): Space, Time and Culture. London, Kluwer Academic

Cross, G.S. (1993): Time and Money: the Making of Consumer Culture. New York, Routledge

Drucker, F.P. (1974): Management. Task, Responsibilities, Practices. New York, Harper \& Row

Evans, C. L. (2003): Distance, Time and Culture. Washington DC, FED Publication

Franses, Ph. H. (1998): Time Series Models for Businss and Economic Forecasting. New York, Cambridge University Press

Gaynor, P.E. (1994): Introduction to Time-series Modeling and Forecasting in Business and Economies. New York, McGraw-Hill
Gollier, Ch. (2001): The Economies of Risk and Time. Cambridge, Mass. MIT Press

Grunbaum, A. (1973): Philosophical Problems of Space and Time. Minneapolis, University of Minnesota Press

Hicks. J.R. (1973): Capital and Time. Oxford, Clarendon Press Hunter, A. (1999): Quick Response: Managing the Supply Chain to Meet Consumer Demand. New York, J. Wiley

Javary, M. (2002): The Economics of Power, Knowledge and Time. Cheltenham (UK), E. Elgar

Katzner, D.W. (1998): Time, Ignorance and Uncertainty in Economic Models. Ann Arbor, University of Michigan Press

Labys, W.C - Takasti, T. - Uri, N.D. (1996): Quantitative Methods for Market-oriented Economic Analysis over Space and Time. Aldershot, Avebury

Managing Time: Expert Solutions to Everyday Challenges. Boston, Mass. Harvard University School Press

McClellen, M. (2003): Collective Manufacturing: Using Real-time Information to Support the Supply Chain. Boca Raton, St. Lucie Press

Moriguchi, Ch. (1967): Business Cycles and Manufacturers' Short-time Production Decision. Amsterdam, NorthHolland Publ.

Nelson, Ch. R. (1973): Applied Time Series Analysis for Managerial Forecasting. San Francisco, Holden-Day

Norro, M. (1962): Le role du temps dans l'intégration économique. Louvain, E. Nauwelaerts

O'Donovan, Th. M. (1983): Sort Term Forecasting: an Introduction to the Box-Jenkins Approach. New York, J. Wiley

Pocker, L. - Apica, A. (2004): The 101 Greatest Business Principles of All Time. New York, Warner Books

Posner, R. A. (1994): Economics, Time and Age. Dublin, Economic and Social Research Institute

Schleifer R. (2000): Modernism and Time. New York, Cambridge University Press

Shalke, G.L.S. (1988): Business, Time and Thought. New York, New York University Press

Simpson, L. Ch. (1994): Technology, Time and the Conversation of Modernity. New York, Routledge

Small Business Deregulation Task Force (1996): Time for Business. Key Findings and Recommendations. Canberra

Spender, D. (1984): Time and Tide Wait for No Man. London, Pandora

Van Fraassen, B.C. (1985): An Introduction to the Philosophy of Time and Space. New York, Columbia University Press

Vigo, A.G. (1996): Zeit und Praxis bei Aristoteles: die Nikomachische Ethik und die zeit-ontologischen Voraussetzungen der vernunftgesteuerten Handels. München, Karl Albert

Winston, G.G. (1982): The Timing of Economic Activities: Firms, Households and Markets in Time-specific Analysis. New York, Cambridge University Press

Cikk beérkezett: 2006. 11. hó

Lektori vélemény alapján átdolgozva: 2007. 6. hó 